\title{
Oceanic and atmospheric methane cycling in the cGENIE Earth system model - release v0.9.14
}

\author{
Christopher T. Reinhard ${ }^{1,2,3}$, Stephanie L. Olson ${ }^{2,4,5}$, Sandra Kirtland Turner ${ }^{6}$, Cecily Pälike ${ }^{7}$, Yoshiki Kanzaki ${ }^{6}$, and \\ Andy Ridgwell ${ }^{6}$ \\ ${ }^{1}$ School of Earth and Atmospheric Sciences, Georgia Institute of Technology, Atlanta, GA 30332, USA \\ ${ }^{2}$ NASA Astrobiology Institute, Alternative Earths Team, Riverside, CA, USA \\ ${ }^{3}$ NASA Nexus for Exoplanet System Science (NExSS) Upside-Down Biospheres Team, \\ Georgia Institute of Technology, Atlanta, GA, USA \\ ${ }^{4}$ Department of Geophysical Sciences, University of Chicago, Chicago, IL 60637, USA \\ ${ }^{5}$ Department of Earth, Atmospheric, and Planetary Science, Purdue University, West Lafayette, IN 47907, USA \\ ${ }^{6}$ Department of Earth and Planetary Sciences, University of California, Riverside, Riverside, CA 92521, USA \\ ${ }^{7}$ MARUM Center for Marine Environmental Sciences, University of Bremen, Bremen, Germany
}

Correspondence: Christopher T. Reinhard (chris.reinhard@eas.gatech.edu)

Received: 30 January 2020 - Discussion started: 9 March 2020

Revised: 27 August 2020 - Accepted: 6 October 2020 - Published: 20 November 2020

\begin{abstract}
The methane $\left(\mathrm{CH}_{4}\right)$ cycle is a key component of the Earth system that links planetary climate, biological metabolism, and the global biogeochemical cycles of carbon, oxygen, sulfur, and hydrogen. However, currently lacking is a numerical model capable of simulating a diversity of environments in the ocean, where $\mathrm{CH}_{4}$ can be produced and destroyed, and with the flexibility to be able to explore not only relatively recent perturbations to Earth's $\mathrm{CH}_{4}$ cycle but also to probe $\mathrm{CH}_{4}$ cycling and associated climate impacts under the very low- $\mathrm{O}_{2}$ conditions characteristic of most of Earth's history and likely widespread on other Earth-like planets. Here, we present a refinement and expansion of the ocean-atmosphere $\mathrm{CH}_{4}$ cycle in the intermediate-complexity Earth system model cGENIE, including parameterized atmospheric $\mathrm{O}_{2}-\mathrm{O}_{3}-\mathrm{CH}_{4}$ photochemistry and schemes for microbial methanogenesis, aerobic methanotrophy, and anaerobic oxidation of methane (AOM). We describe the model framework, compare model parameterizations against modern observations, and illustrate the flexibility of the model through a series of example simulations. Though we make no attempt to rigorously tune default model parameters, we find that simulated atmospheric $\mathrm{CH}_{4}$ levels and marine dissolved $\mathrm{CH}_{4}$ distributions are generally in good agreement with empirical constraints for the modern and recent Earth. Finally, we illustrate the model's utility in understanding the time-
\end{abstract}

dependent behavior of the $\mathrm{CH}_{4}$ cycle resulting from transient carbon injection into the atmosphere, and we present model ensembles that examine the effects of atmospheric $p \mathrm{O}_{2}$, oceanic dissolved $\mathrm{SO}_{4}^{2-}$, and the thermodynamics of microbial metabolism on steady-state atmospheric $\mathrm{CH}_{4}$ abundance. Future model developments will address the sources and sinks of $\mathrm{CH}_{4}$ associated with the terrestrial biosphere and marine $\mathrm{CH}_{4}$ gas hydrates, both of which will be essential for comprehensive treatment of Earth's $\mathrm{CH}_{4}$ cycle during geologically recent time periods.

\section{Introduction}

The global biogeochemical cycle of methane $\left(\mathrm{CH}_{4}\right)$ is central to the evolution and climatic stability of the Earth system. Methane provides an important substrate for microbial metabolism, particularly in energy-limited microbial ecosystems in the deep subsurface (Valentine, 2011; Chapelle et al., 1995) and in anoxic marine and lacustrine sediments (Lovley et al., 1982; Hoehler et al., 2001). Indeed, the microbial production and consumption of $\mathrm{CH}_{4}$ are amongst the oldest metabolisms on Earth, with an isotopic record of bacterial methane cycling stretching back nearly 3.5 billion years (Ueno et al., 2006; Hinrichs, 2002; Hayes, 1994). 
As the most abundant hydrocarbon in Earth's atmosphere $\mathrm{CH}_{4}$ also has a significant influence on atmospheric photochemistry (Thompson and Cicerone, 1986), and because it absorbs in a window region of Earth's longwave emission spectrum it is an important greenhouse gas. This has important implications over the coming centuries, with atmospheric $\mathrm{CH}_{4}$ classified as a critical near-term climate forcing (Myhre et al., 2013), but has also resulted in dramatic impacts during certain periods of Earth's history. For example, high steady-state atmospheric $\mathrm{CH}_{4}$ has been invoked as an important component of Earth's early energy budget, potentially helping to offset a dim early Sun (Sagan and Mullen, 1972; Pavlov et al., 2000; Haqq-Misra et al., 2008), while time-dependent changes to the atmospheric $\mathrm{CH}_{4}$ inventory have been invoked as drivers of extreme climatic perturbations throughout Earth's history (Dickens et al., 1997; Dickens, 2003; Bjerrum and Canfield, 2011; Zeebe, 2013; Schrag et al., 2002). Because it is cycled largely through biological processes on the modern (and ancient) Earth and is spectrally active, atmospheric $\mathrm{CH}_{4}$ has also been suggested as a remotely detectable biosignature that could be applied to planets beyond our solar system (Hitchcock and Lovelock, 1967; Sagan et al., 1993; Krissansen-Totton et al., 2018).

A number of low-order Earth system models incorporating a basic $\mathrm{CH}_{4}$ cycle have been developed, particularly with a view to addressing relatively "deep time" geological questions. These include explorations of long-term changes to the chemistry of Earth's atmosphere (Claire et al., 2006; Catling et al., 2007; Bartdorff et al., 2008; Beerling et al., 2009), potential climate impacts at steady state (Kasting et al., 2001; Ozaki et al., 2018), and transient impacts of $\mathrm{CH}_{4}$ degassing on climate (Schrag et al., 2002; Bjerrum and Canfield, 2011). In some cases these models explicitly couple surface fluxes to a model of atmospheric photochemistry (Lamarque et al., 2006; Ozaki et al., 2018; Kasting et al., 2001), but in general atmospheric chemistry is parameterized based on offline 1-D or 2-D photochemical models, while surface fluxes are specified arbitrarily or are based on a simple one-box oceanbiosphere model. A range of slightly more complex "box" model approaches have been applied to simulate transient perturbations to Earth's $\mathrm{CH}_{4}$ cycle and attendant climate impacts on timescales ranging from $\sim 10^{5}$ years (Dickens et al., 1997; Dickens, 2003) to $\sim 10^{8}$ years (Daines and Lenton, 2016). In addition, offline and/or highly parameterized approaches toward simulating the impact of transient $\mathrm{CH}_{4}$ degassing from gas hydrate reservoirs have been developed and applied to relatively recent periods of Earth's history (Archer and Buffett, 2005; Lunt et al., 2011) or projected future changes (Archer et al., 2009; Hunter et al., 2013). However, the most sophisticated and mechanistic models of global $\mathrm{CH}_{4}$ cycling currently available tend to focus on terrestrial (soil or wetland) sources and sinks (Ridgwell et al., 1999; Walter and Heimann, 2000; Wania et al., 2010; Konijnendijk et al., 2011; Melton et al., 2013) or on explicitly modeling atmospheric photochemistry (Shindell et al., 2013).
Much less work has been done to develop ocean biogeochemistry models that are both equipped to deal with the wide range of boundary conditions characteristic of Earth's history and are computationally tractable when running large model ensembles and/or on long (approaching $\sim 10^{6}$ year) timescales, as well as being able to simulate the (3-D) redox structure of the ocean, allowing for localized zones of production and oxidation (which provides more accurate estimates of emission to the atmosphere). For instance, Elliot et al. (2011) advanced modeling of marine $\mathrm{CH}_{4}$ cycling by developing and employing a 3-D ocean circulation and climate model (CCSM-3) to simulate the impact of injecting clathrate-derived $\mathrm{CH}_{4}$ into the Arctic Ocean. However, microbial consumption of $\mathrm{CH}_{4}$ in the ocean interior was parameterized via an empirical log-linear function that implicitly neglects anaerobic oxidation of methane $(\mathrm{AOM})$ via dissolved sulfate $\left(\mathrm{SO}_{4}^{2-}\right)$, which on the modern Earth is an enormously important internal $\mathrm{CH}_{4}$ sink within Earth's oceans (Egger et al., 2018). Their simulations did not explore atmospheric chemistry. Similarly, Daines and Lenton (2016) also innovated over traditional box modeling approaches by applying an ocean general circulation model (GCM) to examine the role of aerobic methanotrophy in modulating ocean-atmosphere fluxes of $\mathrm{CH}_{4}$ during the Archean (prior to $\sim 2.5$ billion years ago, Ga). However, this analysis likewise did not include AOM, and the GCM results were not coupled to atmospheric chemistry. In contrast, Olson et al. (2016) included AOM in a 3-D ocean biogeochemistry model coupled to an atmospheric chemistry routine and found that $\mathrm{AOM}$ represents a critical internal $\mathrm{CH}_{4}$ sink in the oceans even at relatively low dissolved $\mathrm{SO}_{4}^{2-}$ levels. Though this represented an important further step forward in understanding marine $\mathrm{CH}_{4}$ cycling on the early Earth, Olson et al. (2016) employed a simplified parameterization of aerobic $\mathrm{CH}_{4}$ consumption, neglected the thermodynamics of $\mathrm{CH}_{4}$-consuming metabolisms under energylimited conditions, and employed a parameterization of atmospheric $\mathrm{O}_{2}-\mathrm{O}_{3}-\mathrm{CH}_{4}$ photochemistry that is most readily applicable to only a subset of the atmospheric $p \mathrm{O}_{2}$ values characteristic of Earth's history (Daines and Lenton, 2016; Olson et al., 2016). While all of these studies provided new modeling innovations and advances in understanding, important facets of global $\mathrm{CH}_{4}$ cycling, particularly as relevant to the evolution of the early Earth, were lacking.

Here, we present a new framework for modeling the ocean-atmosphere biogeochemical $\mathrm{CH}_{4}$ cycle in the "muffin" release of the cGENIE Earth system model. Our goal is to make further progress in the development of a flexible intermediate-complexity model suitable for simulating the global biogeochemical $\mathrm{CH}_{4}$ cycle on ocean-bearing planets, with an initial focus on periods of Earth's history (or other habitable planets) that lack a robust terrestrial biosphere. We also aim to provide a numerical modeling foundation from which to further develop a more complete $\mathrm{CH}_{4}$ cycle within the cGENIE framework, including, for example, dynamic 
$\mathrm{CH}_{4}$ hydrate cycling and the production and consumption of $\mathrm{CH}_{4}$ by terrestrial ecosystems.

The outline of the paper is as follows. In Sect. 2 we briefly describe the GENIE-cGENIE Earth system model, with a particular eye toward the features that are most relevant for the biological carbon pump and the oceanic $\mathrm{CH}_{4}$ cycle. In Sect. 3 we describe the major microbial metabolisms involved in the oceanic $\mathrm{CH}_{4}$ cycle and compare our parameterizations to data from modern marine environments. In Sect. 4 we describe two alternative parameterizations of atmospheric $\mathrm{O}_{2}-\mathrm{O}_{3}-\mathrm{CH}_{4}$ photochemistry incorporated into the model and compare these to modern and more recent observations. In Sect. 5 we present results from a series of idealized simulations meant to illustrate the flexibility of the model and some potential applications. The availability of the model code, plus configuration files for all experiments described in the paper, is provided in Sect. 7, following a brief summary in Sect. 6.

\section{The GENIE-cGENIE Earth system model}

\subsection{Ocean physics and climate model - C-GOLDSTEIN}

The ocean physics and climate model in cGENIE are comprised of a reduced physics (frictional geostrophic) 3-D ocean circulation model coupled to both a 2-D energy-moisture balance model (EMBM) and a dynamicthermodynamic sea ice model (Edwards and Marsh, 2005; Marsh et al., 2011). The ocean model transports heat, salinity, and biogeochemical tracers using a scheme of parameterized isoneutral diffusion and eddy-induced advection (Griffies, 1998; Edwards and Marsh, 2005; Marsh et al., 2011), exchanges heat and moisture with the atmosphere, sea ice, and land, and is forced at the ocean surface by the input of zonal and meridional wind stress according to a specified wind field. The 2-D atmospheric energy-moisture balance model (EMBM) considers the heat and moisture balance for the atmospheric boundary layer using air temperature and specific humidity as prognostic tracers. Heat and moisture are mixed horizontally throughout the atmosphere and exchange heat and moisture with the ocean and land surfaces with precipitation occurring above a given relative humidity threshold. The sea ice model tracks the horizontal transport of sea ice and the exchange of heat and fresh water with the ocean and atmosphere using ice thickness, areal fraction, and concentration as prognostic variables. Full descriptions of the model and coupling procedure can be found in Edwards and Marsh (2005) and, more recently, in Marsh et al. (2011). As implemented here, the ocean model is configured as a $36 \times 36$ equal-area grid (uniform in longitude and uniform in the sine of latitude) with 16 logarithmically spaced depth levels and seasonal surface forcing from the EMBM.

\subsection{Ocean biological pump - BIOGEM}

The biogeochemical model component - BIOGEM - regulates air-sea gas exchange as well as the transformation and partitioning of biogeochemical tracers within the ocean, as described in Ridgwell et al. (2007). By default, the biological pump is driven by parameterized uptake of nutrients in the surface ocean, with this flux converted stoichiometrically to biomass that is then partitioned into either dissolved or particulate organic matter for downstream transport, sinking, and remineralization. Dissolved organic matter is transported by the ocean model and decays with a specified time constant, while particulate organic matter is immediately exported out of the surface ocean and partitioned into two fractions of differing lability. In the ocean interior, particulate organic matter is remineralized instantaneously throughout the water column following an exponential decay function with a specified remineralization length scale.

In the simulations discussed below, photosynthetic nutrient uptake in surface ocean grid cells is controlled by a single limiting nutrient, dissolved phosphate $\left(\mathrm{PO}_{4}\right)$ :

$\frac{\partial \mathrm{PO}_{4}}{\partial t}=-\Gamma+\lambda \mathrm{DOP}$,
$\frac{\partial \mathrm{DOP}}{\partial t}=v \Gamma-\lambda \mathrm{DOP}$,

where DOP represents dissolved organic phosphorus, $v$ represents the proportion of photosynthetic production that is initially partitioned into a dissolved organic phase, $\lambda$ represents a decay constant $\left(\right.$ time $^{-1}$ ) for dissolved organic matter, and $\Gamma$ represents photosynthetic nutrient uptake following Doney et al. (2006):

$\Gamma=F_{\mathrm{I}} \cdot F_{\mathrm{N}} \cdot F_{\mathrm{T}} \cdot\left(1-f_{\text {ice }}\right) \cdot \frac{\left[\mathrm{PO}_{4}\right]}{\tau_{\text {bio }}}$.

Rates of photosynthesis are regulated by terms describing the impact of available light $\left(F_{\mathrm{I}}\right)$, nutrient abundance $\left(F_{\mathrm{N}}\right)$, temperature $\left(F_{\mathrm{T}}\right)$, and fractional sea ice coverage in each grid cell $\left(f_{\text {ice }}\right)$. Rates of photosynthetic nutrient uptake are further scaled to ambient dissolved $\mathrm{PO}_{4}\left(\left[\mathrm{PO}_{4}\right]\right)$ according to an optimal uptake timescale ( $\left.\tau_{\text {bio }}\right)$.

Note that this parameterization differs from that in Ridgwell et al. (2007). Specifically, the impacts of light and nutrient availability are both described via Michaelis-Menten terms:

$$
\begin{aligned}
& F_{\mathrm{I}}=\frac{I}{I+\kappa_{\mathrm{I}}}, \\
& F_{\mathrm{N}}=\frac{\left[\mathrm{PO}_{4}^{3-}\right]}{\kappa_{\mathrm{P}}+\left[\mathrm{PO}_{4}^{3-}\right]},
\end{aligned}
$$

where shortwave irradiance $I$ is averaged over the entire mixed layer and is assumed to decay exponentially from the sea surface with a length scale of $20 \mathrm{~m}$. It is assumed that 
nutrient uptake and photosynthetic production only occur in surface grid cells of cGENIE (e.g., the upper $80 \mathrm{~m}$ ), which is similar to the "compensation depth" $z_{\mathrm{c}}$ in Doney et al. (2006) of $75 \mathrm{~m}$. The terms $\kappa_{\mathrm{I}}$ and $\kappa_{\mathrm{P}}$ represent half-saturation constants for light and dissolved phosphate, respectively. In addition, the effect of temperature on nutrient uptake is parameterized according to

$F_{\mathrm{T}}=k_{\mathrm{T} 0} \cdot \exp \left[\frac{T}{k_{\mathrm{eT}}}\right]$,

where $k_{\mathrm{T} 0}$ and $k_{\mathrm{eT}}$ denote pre-exponential and exponential scaling constants and $T$ represents absolute in situ temperature. The scaling constants are chosen to give approximately a factor of 2 change in rate with a temperature change of $10^{\circ} \mathrm{C}$ (e.g., a $Q_{10}$ response of $\sim 2.0$ ). Lastly, the final term in Eq. (3), not present in the default parameterization of Ridgwell et al. (2007), allows biological productivity to scale more directly with available $\mathrm{PO}_{4}$ when dissolved $\mathrm{PO}_{4}$ concentrations are elevated relative to those of the modern oceans.

Particulate organic matter (POM) is immediately exported out of the surface ocean without lateral advection and is instantaneously remineralized throughout the water column according to an exponential function of depth:

$F_{z}^{\mathrm{POM}}=F_{z=z_{h}}^{\mathrm{POM}} \cdot\left(\sum_{i} r_{i}^{\mathrm{POM}} \cdot \exp \left(\frac{z_{h}-z}{l_{i}^{\mathrm{POM}}}\right)\right)$,

where $F_{z}^{\mathrm{POM}}$ is the particulate organic matter flux at a given depth (and $z_{h}$ is the base of the photic zone), $z$ is depth, and $r_{i}^{\mathrm{POM}}$ and $l_{i}^{\mathrm{POM}}$ refer to the relative partitioning into each organic matter lability fraction $i$ and the $e$-folding depth of that fraction, respectively. The simulations presented here employ two organic matter fractions, a "labile" fraction (94.5\%) with an $e$-folding depth of $\sim 590 \mathrm{~m}$ and an effectively inaccessible fraction $(5.5 \%)$ with an $e$-folding depth of $10^{6} \mathrm{~m}$ (Table 1).

We employ a revised scheme for organic matter remineralization in the ocean interior, following that commonly used in models of organic matter remineralization within marine and lacustrine sediments (Rabouille and Gaillard, 1991; Van Cappellen et al., 1993; Boudreau, 1996a, b). Respiratory electron acceptors $\left(\mathrm{O}_{2}, \mathrm{NO}_{3}^{-}\right.$, and $\left.\mathrm{SO}_{4}^{2-}\right)$ are consumed according to decreasing free energy yield (Froelich et al., 1979), with consumption rates $\left(R_{i}\right)$ scaled to both electron acceptor abundance and the inhibitory impact of electron acceptors with higher intrinsic free energy yield:

$$
\begin{aligned}
& R_{\mathrm{O}_{2}}=\frac{\left[\mathrm{O}_{2}\right]}{\kappa_{\mathrm{O}_{2}}+\left[\mathrm{O}_{2}\right]}, \\
& R_{\mathrm{NO}_{3}}=\frac{\left[\mathrm{NO}_{3}\right]}{\kappa_{\mathrm{NO}_{3}}+\left[\mathrm{NO}_{3}\right]} \cdot \frac{\kappa_{\mathrm{O}_{2}}^{\mathrm{i}}}{\kappa_{\mathrm{O}_{2}}^{\mathrm{i}}+\left[\mathrm{O}_{2}\right]}, \\
& R_{\mathrm{SO}_{4}}=\frac{\left[\mathrm{SO}_{4}\right]}{\kappa_{\mathrm{SO}_{4}}+\left[\mathrm{SO}_{4}\right]} \cdot \frac{\kappa_{\mathrm{O}_{2}}^{\mathrm{i}}}{\kappa_{\mathrm{O}_{2}}^{\mathrm{i}}+\left[\mathrm{O}_{2}\right]} \cdot \frac{\kappa_{\mathrm{NO}_{3}}^{\mathrm{i}}}{\kappa_{\mathrm{NO}_{3}}+\left[\mathrm{NO}_{3}\right]},
\end{aligned}
$$

with the exception that in the biogeochemical configuration used here we do not consider nitrate $\left(\mathrm{NO}_{3}^{-}\right)$. The total consumption of settling POM within each ocean layer is governed by the predetermined remineralization profiles (Eq. 7). The $R_{i}$ terms denote the relative fraction of this organic matter consumption that is performed by each respiratory process. We specify a closed system with no net organic matter burial in marine sediments (see below), and hence the POM flux to the sediment surface is assumed to be completely degraded, with the same partitioning amongst electron acceptors carried out according to local bottom water chemistry. For DOM, the assumed lifetime $(\lambda)$ determines the total fraction of DOM degraded (and Eqs. 8-10 again determine how the consumption of electron acceptors is partitioned). The $\kappa_{i}$ terms represent half-saturation constants for each metabolism, the $\kappa_{i}^{\mathrm{i}}$ terms give inhibition constants acting on less energetic downstream respiratory processes, and brackets denote concentration. Default parameter values used here are shown in Table 1.

\section{Oceanic methane cycling}

\subsection{Microbial methanogenesis}

Methanogenesis represents the terminal step in our remineralization scheme and follows the overall stoichiometry:

$2 \mathrm{CH}_{2} \mathrm{O} \rightarrow \mathrm{CH}_{4}+\mathrm{CO}_{2}$.

This can be taken to implicitly include fermentation of organic matter to acetate followed by acetoclastic methanogenesis:

$2 \mathrm{CH}_{2} \mathrm{O} \rightarrow \mathrm{CH}_{3} \mathrm{COOH}$,

$\mathrm{CH}_{3} \mathrm{COOH} \rightarrow \mathrm{CH}_{4}+\mathrm{CO}_{2}$,

or the fermentation of organic matter to acetate followed by anaerobic acetate oxidation and hydrogenotrophic methanogenesis:

$2 \mathrm{CH}_{2} \mathrm{O} \rightarrow \mathrm{CH}_{3} \mathrm{COOH}$,

$\mathrm{CH}_{3} \mathrm{COOH}+2 \mathrm{H}_{2} \mathrm{O} \rightarrow 4 \mathrm{H}_{2}+2 \mathrm{CO}_{2}$,

$4 \mathrm{H}_{2}+\mathrm{CO}_{2} \rightarrow \mathrm{CH}_{4}+2 \mathrm{H}_{2} \mathrm{O}$,

both of which have the same overall net stoichiometry provided that $\mathrm{H}_{2}$ is assumed to be quantitatively converted to $\mathrm{CH}_{4}$ by hydrogenotrophic methanogens. We thus ignore the scenario in which some fraction of $\mathrm{H}_{2}$ is converted directly to biomass by hydrogenotrophic methanogens acting as primary producers (Ozaki et al., 2018).

Because we specify a closed system with no net organic matter burial in marine sediments, all organic matter not remineralized by more energetic respiratory metabolisms is converted into $\mathrm{CH}_{4}$ (e.g., $R_{\mathrm{CH}_{4}}=1-R_{\mathrm{O}_{2}}-R_{\mathrm{NO}_{3}}-R_{\mathrm{SO}_{4}}$ ):

$R_{\mathrm{CH}_{4}}=\frac{\kappa_{\mathrm{O}_{2}}^{\mathrm{i}}}{\kappa_{\mathrm{O}_{2}}^{\mathrm{i}}+\left[\mathrm{O}_{2}\right]} \cdot \frac{\kappa_{\mathrm{NO}_{3}}^{\mathrm{i}}}{\kappa_{\mathrm{NO}_{3}}+\left[\mathrm{NO}_{3}\right]} \cdot \frac{\kappa_{\mathrm{SO}_{4}}^{\mathrm{i}}}{\kappa_{\mathrm{SO}_{4}}+\left[\mathrm{SO}_{4}\right]}$, 
Table 1. Default parameters for organic matter production and water column remineralization.

\begin{tabular}{|c|c|c|c|c|}
\hline Parameter & Description & Default value & Units & Source \\
\hline \multicolumn{5}{|c|}{ Uptake and photosynthesis } \\
\hline$\lambda$ & rate constant for DOM degradation & 0.5 & $\mathrm{yr}^{-1}$ & 1 \\
\hline$v$ & fractional partitioning into DOM & 0.66 & - & 1 \\
\hline$\tau_{\text {bio }}$ & nutrient uptake timescale & 63 & $\mathrm{~d}$ & 2 \\
\hline$\kappa_{\mathrm{I}}$ & light limitation term & 20 & $\mathrm{~W} \mathrm{~m}^{-2}$ & 3 \\
\hline$\kappa \mathrm{P}$ & half-saturation constant for $\mathrm{PO}_{4}$ uptake & $2.1 \times 10^{-7}$ & $\mathrm{~mol} \mathrm{~kg}^{-1}$ & 1 \\
\hline$k_{\mathrm{T} 0}$ & pre-exponential temperature constant & 0.59 & - & (see text) \\
\hline$k_{\mathrm{eT}}$ & exponential temperature constant & 15.8 & - & (see text) \\
\hline \multicolumn{5}{|c|}{ Organic remineralization } \\
\hline$r_{1}^{\mathrm{POM}}$ & partitioning into labile POM fraction & 0.945 & - & 1 \\
\hline$l_{1}^{\mathrm{POM}}$ & $e$-folding depth for labile POM fraction & 589 & $\mathrm{~m}$ & (see text) \\
\hline$r_{2}^{\mathrm{POM}}$ & partitioning into refractory POM fraction & 0.055 & - & 4 \\
\hline$l_{2}^{\mathrm{POM}}$ & $e$-folding depth for recalcitrant POM fraction & $10^{6}$ & $\mathrm{~m}$ & (see text) \\
\hline$\kappa_{\mathrm{O}_{2}}$ & half-saturation constant for aerobic respiration & $1.0 \times 10^{-7}$ & $\mathrm{~mol} \mathrm{~kg}^{-1}$ & (see text) \\
\hline$\kappa_{\mathrm{O}_{2}}^{\mathrm{i}}$ & inhibition constant for aerobic respiration & $1.0 \times 10^{-6}$ & $\mathrm{~mol} \mathrm{~kg}^{-1}$ & $($ see text) \\
\hline$\kappa \mathrm{SS}_{4}$ & half-saturation constant for sulfate reduction & $5.0 \times 10^{-4}$ & $\mathrm{~mol} \mathrm{~kg}^{-1}$ & 4 \\
\hline$\kappa_{\mathrm{SO}_{4}}^{\mathrm{i}}$ & Inhibition constant for sulfate reduction & $5.0 \times 10^{-4}$ & $\mathrm{~mol} \mathrm{~kg}^{-1}$ & 4 \\
\hline
\end{tabular}

${ }^{1}$ Ridgwell et al. (2007); ${ }^{2}$ Meyer et al. (2016); ${ }^{3}$ Doney et al. (2006); ${ }^{4}$ Olson et al. (2016).

where the $\kappa_{i}$ and $\kappa_{i}^{\mathrm{i}}$ terms are as described above (Table 1). We disable nitrate $\left(\mathrm{NO}_{3}\right)$ as a tracer in the simulations presented here such that anaerobic remineralization of organic matter is partitioned entirely between sulfate reduction and methanogenesis (Fig. 1). Using our default parameter values (Table 1), aerobic respiration dominates organic matter remineralization at $\left[\mathrm{O}_{2}\right]$ values significantly above $1 \mu \mathrm{mol} \mathrm{kg}{ }^{-1}$ (Fig. 1a), while anaerobic remineralization is dominated by methanogenesis at $\left[\mathrm{SO}_{4}^{2-}\right]$ values significantly below $1 \mathrm{mmol} \mathrm{kg}^{-1}$ (Fig. 1b). An important outcome of the revised "inhibition" scheme is that metabolic pathways with differing intrinsic free energy yields can coexist, which more accurately reflects field observations from a range of natural settings (Curtis, 2003; Bethke et al., 2008; Kuivila et al., 1989; Jakobsen and Postma, 1999). In particular, it allows us to roughly capture the impact of oxidant gradients within sinking marine aggregates (Bianchi et al., 2018), which can facilitate nontrivial anaerobic carbon remineralization within sinking particles even in the presence of relatively high $\left[\mathrm{O}_{2}\right]$ in the ocean water column (Fig. 1c).

While the model tracks the carbon isotope composition of oceanic and atmospheric $\mathrm{CH}_{4}\left(\delta^{13} \mathrm{C}\right.$, reported in per mill notation relative to the Pee Dee Belemnite, PDB), the only significant isotope effect we include here is that attendant to acetoclastic methanogenesis. We specify a constant isotope fractionation between organic carbon and $\mathrm{CH}_{4}$ during methanogenesis of $-35 \%$ ob default (Table 2), which will tend to produce microbial $\mathrm{CH}_{4}$ with a $\delta^{13} \mathrm{C}$ composition of roughly $-60 \%$ when combined with the default isotope fractionation associated with photosynthetic carbon fixation in the surface ocean (e.g., Kirtland Turner and Ridgwell, 2016). The model does not currently include any potential isotope effects associated with aerobic and anaerobic methanotrophy, air-sea gas exchange of $\mathrm{CH}_{4}$, or photochemical breakdown of $\mathrm{CH}_{4}$ in the atmosphere. It does, however, include a comprehensive ${ }^{13} \mathrm{C}$ scheme associated with ocean-atmosphere cycling of $\mathrm{CO}_{2}$ (Kirtland Turner and Ridgwell, 2016; Ridgwell, 2001).

\subsection{Aerobic methanotrophy}

Microbial aerobic methanotrophy proceeds according to

$\mathrm{CH}_{4}+2 \mathrm{O}_{2} \rightarrow \mathrm{CO}_{2}+2 \mathrm{H}_{2} \mathrm{O}$.

This reaction is highly favorable energetically, with a free energy yield under standard conditions of $\sim 850 \mathrm{~kJ}$ per mole of methane consumed (Table 2). We represent rates of aerobic methanotrophy $\left(R_{\mathrm{AER}}\right)$ with a mixed kinetic-thermodynamic formulation (Jin and Bethke, 2005, 2007; Regnier et al., 2011), in which $\mathrm{CH}_{4}$ oxidation kinetics are controlled by substrate availability, thermodynamic energy yield, and temperature:

$R_{\mathrm{AER}}=k_{\mathrm{AER}} \cdot F_{k}^{\mathrm{AER}} \cdot F_{t}^{\mathrm{AER}} \cdot F_{\mathrm{T}}$.

A rate constant for aerobic methanotrophy $\left(\mathrm{yr}^{-1}\right)$ is defined as $k_{\mathrm{AER}}$, while $F_{i}$ terms denote kinetic $(k)$ and thermodynamic $(t)$ factors as defined below and a temperature $(T)$ factor as given in Eq. (6) above. 
(a)

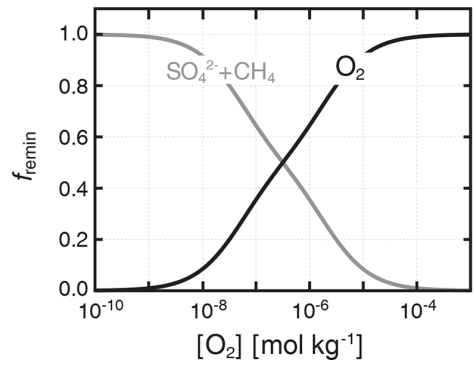

(b)

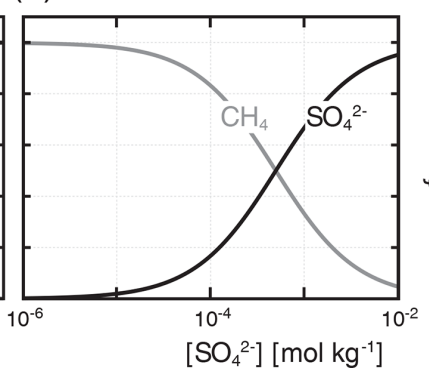

(c)

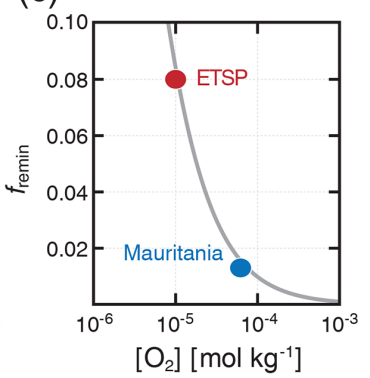

Figure 1. Fractional organic carbon remineralization by aerobic respiration, sulfate reduction, and methanogenesis in our modified organic matter remineralization scheme. In (a), relative rates of aerobic $\left(\mathrm{O}_{2}\right)$ and anaerobic $\left(\mathrm{SO}_{4}^{2-}+\mathrm{CH}_{4}\right)$ remineralization are plotted as a function of dissolved $\left[\mathrm{O}_{2}\right]$. In (b), relative anaerobic remineralization rates are partitioned between sulfate reduction and methanogenesis as a function of dissolved $\left[\mathrm{SO}_{4}^{2-}\right]$ (dissolved $\left[\mathrm{O}_{2}\right]$ is held constant at $10^{-10} \mathrm{~mol} \mathrm{~kg}{ }^{-1}$ ). Shown in $(\mathbf{c})$ are our estimated anaerobic remineralization fractions (grey curve) compared to estimates from a particle biogeochemical model applied to oxygen minimum zones (OMZs) in the eastern tropical South Pacific (ETSP) and Mauritanian upwelling (Bianchi et al., 2018).

Table 2. Default kinetic and thermodynamic parameters for oceanic methane cycling. Activity coefficients are estimated for $T=25^{\circ} \mathrm{C}$ and $S=35 \%$.

\begin{tabular}{|c|c|c|c|c|}
\hline Parameter & Description & Default value & Units & Source \\
\hline \multicolumn{5}{|c|}{ Kinetic parameters } \\
\hline$k_{\mathrm{AER}}$ & rate constant for aerobic methanotrophy & 0.10 & $\mathrm{yr}^{-1}$ & (see text) \\
\hline$\kappa_{\mathrm{O}}^{\mathrm{AER}}$ & half-saturation constant for $\mathrm{O}_{2}$ & $2.0 \times 10^{-5}$ & $\mathrm{~mol} \mathrm{~kg}^{-1}$ & (see text) \\
\hline$k_{\mathrm{AOM}}$ & rate constant for $\mathrm{AOM}$ & 0.01 & $\mathrm{yr}^{-1}$ & (see text) \\
\hline$\kappa_{\mathrm{S}}^{\mathrm{AOM}}$ & AOM half-saturation constant for $\mathrm{SO}_{4}^{2-}$ & $5.0 \times 10^{-4}$ & $\mathrm{~mol} \mathrm{~kg}^{-1}$ & 1 \\
\hline \multicolumn{5}{|c|}{ Thermodynamic parameters } \\
\hline$\Delta G_{\mathrm{r}, \mathrm{AER}}^{0}$ & standard free energy yield of aerobic methanotrophy & -858.967 & $\mathrm{~kJ} \mathrm{~mol}^{-1}$ & 2 \\
\hline$\Delta G_{\mathrm{r}, \mathrm{AOM}}^{0}$ & standard free energy yield of AOM & -33.242 & $\mathrm{~kJ} \mathrm{~mol}^{-1}$ & 2 \\
\hline$\Delta G_{\mathrm{BQ}, \mathrm{AER}}$ & minimum free energy for aerobic methanotrophy & -15.0 & $\mathrm{~kJ} \mathrm{~mol}^{-1}$ & (see text) \\
\hline$\Delta G_{\mathrm{BQ}, \mathrm{AOM}}$ & minimum free energy for $\mathrm{AOM}$ & -15.0 & $\mathrm{~kJ} \mathrm{~mol}^{-1}$ & $2-5$ \\
\hline$\gamma_{\mathrm{CH}_{4}}$ & activity coefficient for dissolved $\mathrm{CH}_{4}$ & 1.20 & - & $6-8$ \\
\hline$\gamma_{\mathrm{CO}_{2}}$ & activity coefficient for aqueous $\mathrm{CO}_{2}$ & 1.17 & - & 9 \\
\hline$\gamma_{\mathrm{O}_{2}}$ & activity coefficient for dissolved $\mathrm{O}_{2}$ & 1.14 & - & 10 \\
\hline$\gamma_{\mathrm{HCO}_{3}^{-}}$ & activity coefficient for dissolved $\mathrm{HCO}_{3}^{-}$ & 0.58 & - & 11,12 \\
\hline$\gamma_{\mathrm{HS}^{-}}$ & activity coefficient for dissolved $\mathrm{HS}^{-}$ & 0.75 & - & 13 \\
\hline$\gamma_{\mathrm{SO}_{4}^{2-}}$ & activity coefficient for dissolved $\mathrm{SO}_{4}^{2-}$ & 0.10 & - & 11 \\
\hline$R^{4}$ & gas constant & $8.2144 \times 10^{-3}$ & $\mathrm{~kJ} \mathrm{~K}^{-1} \mathrm{~mol}^{-1}$ & \\
\hline$\chi$ & stoichiometric number & 1.0 & - & 14 \\
\hline \multicolumn{5}{|c|}{ Isotopic parameters } \\
\hline$\varepsilon_{\mathrm{CH}_{4}}$ & methanogenesis isotope effect & -35.0 & $\%$ & (see text) \\
\hline
\end{tabular}

The kinetic factor $\left(F_{k}\right)$ for aerobic methanotrophy is controlled by substrate availability according to

$F_{k}^{\mathrm{AER}}=\left[\mathrm{CH}_{4}\right] \cdot \frac{\left[\mathrm{O}_{2}\right]}{\kappa_{\mathrm{O}}^{\mathrm{AER}}+\left[\mathrm{O}_{2}\right]}$, where brackets denote concentration and the $\kappa$ term denotes a half-saturation constant with respect to $\mathrm{O}_{2}$. We employ a hybrid parameterization in which kinetics are first-order with respect to $\mathrm{CH}_{4}$ but also scaled by a Michaelis-Menten-type term for $\mathrm{O}_{2}$. This formulation is based on the rationale that half-saturation constants for $\mathrm{CH}_{4}$ are typically similar to (or 
greater than) the dissolved $\mathrm{CH}_{4}$ levels attained in anoxic water column environments (Regnier et al., 2011) but is also meant to allow for rapid $\mathrm{CH}_{4}$ consumption under "bloom" conditions with an appropriately scaled rate constant (see below).

The effect of thermodynamic energy yield on aerobic methanotrophy is given by

$$
F_{t}^{\mathrm{AER}}=1-\exp \left[\frac{\Delta G_{\mathrm{r}, \mathrm{AER}}+\Delta G_{\mathrm{BQ}, \mathrm{AER}}}{\chi R T}\right],
$$

where $\Delta G_{\mathrm{r}}$ denotes the Gibbs free energy of reaction under in situ conditions, $\Delta G_{\mathrm{BQ}}$ represents the minimum energy required to sustain ATP synthesis (Hoehler et al., 2001; Hoehler, 2004; Jin and Bethke, 2007), $\chi$ is the stoichiometric number of the reaction (e.g., the number of times the ratedetermining step occurs in the overall process), and $R$ and $T$ represent the gas constant and absolute in situ temperature, respectively. The available free energy is estimated according to

$$
\Delta G_{\mathrm{r}, \mathrm{AER}}=\Delta G_{\mathrm{r}, \mathrm{AER}}^{0}+R T \cdot \ln \frac{\gamma_{\mathrm{CO}_{2}}\left[\mathrm{CO}_{2}\right]}{\gamma_{\mathrm{O}_{2}}\left[\mathrm{O}_{2}\right] \cdot \gamma_{\mathrm{CH}_{4}}\left[\mathrm{CH}_{4}\right]},
$$

where, in addition to the terms defined above, $\Delta G_{\mathrm{r}}^{0}$ represents the Gibbs free energy of the reaction under standard conditions, and $\gamma_{i}$ values represent activity coefficients. Note that we assume an $\mathrm{H}_{2} \mathrm{O}$ activity of unity.

\subsection{Anaerobic oxidation of methane (AOM)}

The oxidation of methane can also be coupled to electron acceptors other than $\mathrm{O}_{2}$, including nitrate $\left(\mathrm{NO}_{3}^{-}\right)$, sulfate $\left(\mathrm{SO}_{4}^{2-}\right)$, and oxide phases of iron $(\mathrm{Fe})$ and manganese $(\mathrm{Mn})$ (Reeburgh, 1976; Martens and Berner, 1977; Hoehler et al., 1994; Hinrichs et al., 1999; Orphan et al., 2001; Sivan et al., 2011; Haroon et al., 2013; Egger et al., 2015). Because it is by far the most abundant of these oxidants on the modern Earth and has likely been the most abundant throughout Earth's history, we focus on anaerobic oxidation of methane $(\mathrm{AOM})$ at the expense of $\mathrm{SO}_{4}^{2-}$ :

$\mathrm{CH}_{4}+\mathrm{SO}_{4}^{2-} \rightarrow \mathrm{HCO}_{3}^{-}+\mathrm{HS}^{-}+\mathrm{H}_{2} \mathrm{O}$.

This process is currently thought to be performed most often through a syntrophic association between Archaea and sulfate-reducing bacteria (Boetius et al., 2000), though the mechanics controlling the exchange of reducing equivalents within the syntrophy remain to be fully elucidated (Milucka et al., 2012; McGlynn et al., 2015). In any case, consumption of $\mathrm{CH}_{4}$ at the sulfate-methane transition zone (SMTZ) represents an extremely large sink flux of $\mathrm{CH}_{4}$ in modern marine sediments (Regnier et al., 2011; Egger et al., 2018).

Anaerobic methanotrophy is much less energetically favorable under standard conditions, with a free energy yield of $\sim 30 \mathrm{~kJ}$ per mole of $\mathrm{CH}_{4}$ (Table 2). As a result, the influence of thermodynamics on rates of AOM is potentially much stronger than it will tend to be in the case of aerobic methanotrophy. As above, rates of AOM are controlled by the combined

$R_{\mathrm{AOM}}=k_{\mathrm{AOM}} \cdot F_{k}^{\mathrm{AOM}} \cdot F_{t}^{\mathrm{AOM}} \cdot F_{\mathrm{T}}$,

where $k_{\mathrm{AOM}}$ is a rate constant for anaerobic methane oxidation $\left(\mathrm{yr}^{-1}\right)$, while $F_{i}$ terms denote kinetic $(k)$ and thermodynamic $(t)$ factors as defined below and a temperature $(T)$ factor as given in Eq. (6) above.

The kinetics of anaerobic methane oxidation are specified according to

$$
F_{k}^{\mathrm{AOM}}=\left[\mathrm{CH}_{4}\right] \cdot \frac{\left[\mathrm{SO}_{4}^{2-}\right]}{\kappa_{\mathrm{S}}^{\mathrm{AOM}}+\left[\mathrm{SO}_{4}^{2-}\right]},
$$

where brackets denote concentration and the $\kappa$ term denotes a half-saturation constant with respect to $\mathrm{SO}_{4}^{2-}$. We employ a hybrid parameterization in which kinetics are first-order with respect to $\mathrm{CH}_{4}$ but are also scaled by a Michaelis-Mententype term for $\mathrm{SO}_{4}^{2-}$ for reasons discussed above.

The effect of thermodynamic energy yield on anaerobic methane oxidation is specified as follows:

$F_{t}^{\mathrm{AOM}}=1-\exp \left[\frac{\Delta G_{\mathrm{r}, \mathrm{AOM}}+\Delta G_{\mathrm{BQ}, \mathrm{AOM}}}{\chi R T}\right]$.

As above, $\Delta G_{\mathrm{r}}$ denotes the Gibbs free energy of reaction under in situ conditions, $\Delta G_{\mathrm{BQ}}$ is the minimum energy required to sustain ATP synthesis (the "biological quantum"), $\chi$ is the stoichiometric number of the reaction, and $R$ and $T$ represent the gas constant and absolute in situ temperature, respectively. The available free energy for AOM under in situ conditions is estimated according to

$$
\begin{aligned}
\Delta G_{\mathrm{r}, \mathrm{AOM}}= & \Delta G_{\mathrm{r}, \mathrm{AOM}}^{0}+R T \\
& \cdot \ln \frac{\gamma_{\mathrm{HCO}_{3}^{-}}\left[\mathrm{HCO}_{3}^{-}\right] \cdot \gamma_{\mathrm{HS}^{-}}\left[\mathrm{HS}^{-}\right]}{\gamma_{\mathrm{SO}_{4}^{2-}}\left[\mathrm{SO}_{4}^{2-}\right] \cdot \gamma_{\mathrm{CH}_{4}}\left[\mathrm{CH}_{4}\right]},
\end{aligned}
$$

where $\Delta G_{\mathrm{r}}^{0}$ again represents the Gibbs free energy of the net AOM reaction given above under standard conditions, and $\gamma_{i}$ values represent activity coefficients. Again, we assume an $\mathrm{H}_{2} \mathrm{O}$ activity of unity.

\subsection{Default parameters for aerobic and anaerobic methanotrophy}

We choose default rate constants according to a dataset of compiled rates of aerobic and anaerobic methanotrophy in oxygenated and anoxic marine water column environments (see the Supplement), after correction to in situ temperature (Fig. 2a, b). Our default values for both rate constants are on the low end of the observational dataset but are very roughly tuned to yield steady-state diffusive $\mathrm{CH}_{4}$ fluxes from the ocean that are consistent with recent observational constraints (Fig. 2c). It is important to note, however, that these 
(a)

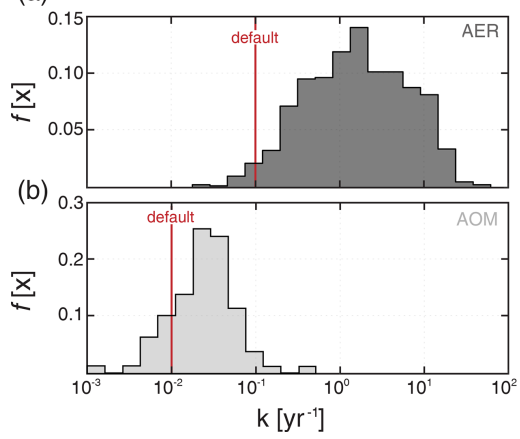

(c)

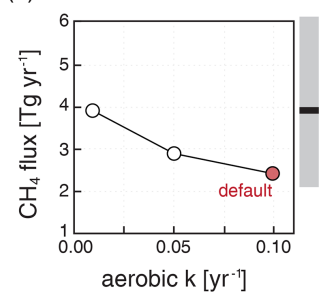

Figure 2. Compilation of rate constants for aerobic (AER; a) and anaerobic (AOM; b) methane oxidation. Rate constants are corrected for in situ temperature using a $Q_{10}$ of 2 (see the Supplement). Vertical red lines show our default values as reported in Table 2. Shown in (c) are globally integrated diffusive fluxes of $\mathrm{CH}_{4}$ from the ocean for a range of rate constants for aerobic methanotrophy, including our default simulation. The bar to the right of (c) shows the median (black bar) and $90 \%$ credible interval (grey shading) for estimates of the modern oceanic diffusive flux from Weber et al. (2019).

values are not extensively tuned and could be adjusted depending on the application. For example, transient $\mathrm{CH}_{4}$ release experiments could employ rate constants that are scaled upward to reflect transient (bloom) elevations in microbial community $\mathrm{CH}_{4}$ consumption as observed in field studies (Kessler et al., 2011; Crespo-Medina et al., 2014). Default values for other kinetic parameters (Table 2) are chosen to be broadly consistent with field measurements and pure or mixed culture experiments with aerobic methanotrophs (Bender and Conrad, 1992, 1993; Hanson and Hanson, 1996; Dunfield and Conrad, 2000; van Bodegom et al., 2001), as well as to remain roughly consistent with previous work for comparative purposes (e.g., Olson et al., 2016), though the parameters have not been formally tuned and we explore model sensitivity below.

Thermodynamic energy yields of each reaction under standard conditions are calculated based on the standard molal thermodynamic properties given in Regnier et al. (2011). Stoichiometric numbers are assumed identical for both metabolisms, with default values of 1.0 (Jin and Bethke, 2005; Dale et al., 2006). We assume a default biological quantum $\left(\Delta G_{\mathrm{BQ}}\right)$ of $15 \mathrm{~kJ} \mathrm{~mol}^{-1}$ for both aerobic and anaerobic methanotrophy, though these can be expected to vary somewhat as a function of metabolism and environmental conditions (Schink, 1997; Hoehler, 2004; Dale et al., 2008). These can be varied independently for aerobic and anaerobic methanotrophy in the model, and we explore model sensitivity to this parameter below. Lastly, for simplicity and to minimize computational expense we assume constant activity coefficients for each species throughout all ocean grid cells (Table 2). For some applications it may ultimately be important to add a scheme for estimating activity coefficients according to ambient salinity and ion chemistry, for example estimating methane fluxes in planetary scenarios with very different major ion chemistry or much higher or lower salinity than those characteristic of Earth's modern oceans.

\section{Atmospheric methane cycling}

\subsection{Air-sea gas exchange}

Ocean-atmosphere fluxes of $\mathrm{CH}_{4}\left(J_{\text {gas }}\right)$ are governed by temperature- and salinity-dependent solubility and surface wind speed above a given grid cell:

$J_{\text {gas }}=A \cdot k_{\text {gas }} \cdot\left(\left[\mathrm{CH}_{4}\right]_{\text {sat }}-\left[\mathrm{CH}_{4}\right]_{\text {cell }}\right)$,

where $A$ denotes the area available for gas exchange (e.g., the area of ice-free surface ocean), $\left[\mathrm{CH}_{4}\right]_{\text {cell }}$ denotes the ambient dissolved $\mathrm{CH}_{4}$ concentration in a given surface ocean grid cell, $\left[\mathrm{CH}_{4}\right]_{\text {sat }}$ represents the dissolved $\mathrm{CH}_{4}$ concentration at saturation with a given atmospheric $p \mathrm{CH}_{4}$, temperature, and salinity, and $k_{\text {gas }}$ represents a gas transfer velocity. Solubility is based on a Bunsen solubility coefficient $(\beta)$ corrected for ambient temperature $(T)$ and salinity $(S)$ according to

$$
\begin{aligned}
\ln \beta= & a_{1}+a_{2}(100 / T)+a_{3} \ln (T / 300) \\
& +S\left[b_{1}+b_{2}(T / 100)+b_{3}(T / 100)^{2}\right] .
\end{aligned}
$$

Note that the Henry's law constant $K_{0}$ is related to the Bunsen solubility coefficient by $K_{0}=\beta / \rho V^{+}$, where $\rho$ is density and $V^{+}$is the molar volume of the gas at standard temperature and pressure (STP). Gas transfer velocity $\left(k_{\mathrm{gas}}\right)$ is calculated based on the surface wind speed $(u)$ and a Schmidt number $(S c)$ corrected for temperature assuming a constant salinity of $35 \%$ :

$k_{\mathrm{gas}}=k \cdot u^{2} \cdot[S c / 660]^{-0.5}$,

where $k$ is a dimensionless gas transfer coefficient, $u$ is surface wind speed, and $S c$ is the temperature-corrected Schmidt number according to

$S c=c_{1}-c_{2} T+c_{3} T^{2}-c_{4} T^{3}$.

All default constants and coefficients for the gas exchange scheme are given in Table 3. Overall, the scheme for air-sea gas exchange of $\mathrm{CH}_{4}$ follows by default that for other gases accounted for in BIOGEM, such as $\mathrm{O}_{2}$ and $\mathrm{CO}_{2}$, as described in Ridgwell et al. (2007)

\subsection{Parameterized $\mathrm{O}_{2}-\mathrm{O}_{3}-\mathrm{CH}_{4}$ photochemistry}

Once degassed to the atmosphere, $\mathrm{CH}_{4}$ becomes involved in a complex series of photochemical reactions initiated by hydroxyl radical $(\mathrm{OH})$ attack on $\mathrm{CH}_{4}$ (Kasting et al., 1983; Prather, 1996; Pavlov et al., 2000; Schmidt and Shindell, 2003). Following Claire et al. (2006) and Goldblatt et 
Table 3. Default constants and coefficients for $\mathrm{CH}_{4}$ gas exchange. All default parameter values are derived from Wanninkhof (1992). Schmidt number coefficients are for $S=35 \%$.

\begin{tabular}{llr}
\hline Parameter & Description & Default value \\
\hline$a_{1}$ & Bunsen temperature coefficient 1 & -68.8862 \\
$a_{2}$ & Bunsen temperature coefficient 2 & 101.4956 \\
$a_{3}$ & Bunsen temperature coefficient 3 & 28.7314 \\
$b_{1}$ & Bunsen salinity coefficient 1 & -0.076146 \\
$b_{2}$ & Bunsen salinity coefficient 2 & 0.043970 \\
$b_{3}$ & Bunsen salinity coefficient 3 & -0.0068672 \\
$c_{1}$ & Schmidt temperature coefficient 1 & 2039.2 \\
$c_{2}$ & Schmidt temperature coefficient 2 & 120.31 \\
$c_{3}$ & Schmidt temperature coefficient 3 & 3.4209 \\
$c_{4}$ & Schmidt temperature coefficient 4 & 0.040437 \\
$k$ & Gas exchange constant & 0.31 \\
\hline
\end{tabular}

al. (2006), we parameterize $\mathrm{O}_{2}-\mathrm{O}_{3}-\mathrm{CH}_{4}$ photochemistry according to a bimolecular "rate law":

$J_{\mathrm{CH}_{4}}=k_{\mathrm{eff}} \cdot M_{\mathrm{O}_{2}} \cdot M_{\mathrm{CH}_{4}}$,

where $M_{i}$ terms represent the atmospheric inventories of $\mathrm{O}_{2}$ and $\mathrm{CH}_{4}$, respectively, and $k_{\text {eff }}$ denotes an effective rate constant $\left(\mathrm{Tmol}^{-1} \mathrm{yr}^{-1}\right)$ that is itself a complicated function of atmospheric $\mathrm{O}_{2}, \mathrm{CH}_{4}$, and $\mathrm{CO}_{2}$ (Claire et al., 2006). We note that in this parameterization, $\mathrm{O}_{3}$ abundance is not calculated explicitly, but rather the photochemical destruction rate of $\mathrm{CH}_{4}$ in the atmosphere is controlled by the combined atmospheric chemistry implicitly embedded within $k_{\text {eff }}$ (Goldblatt et al., 2006; Claire et al., 2006).

At each time step, the distribution of chemical species (e.g., other than temperature and humidity) in the atmosphere is homogenized (Ridgwell et al., 2007) and $k_{\text {eff }}$ is estimated based on the resulting instantaneous mean partial pressures of $\mathrm{O}_{2}$ and $\mathrm{CH}_{4}$ according to a bivariate fit to a large suite of 1-D atmospheric photochemical models. These photochemical model results (Mark Claire, personal communication, 2016) are derived following Claire et al. (2006). Briefly, values for $k_{\text {eff }}$ are computed by a 1-D model of atmospheric photochemistry assuming a range of fixed surface mixing ratios of $\mathrm{O}_{2}$ and $\mathrm{CH}_{4}$ and a constant atmospheric $\mathrm{CO}_{2}$ of $10^{-2}$ bar. We then fit a fifth-order polynomial surface to these $k_{\text {eff }}$ values as a function of atmospheric $p \mathrm{O}_{2}$ and $p \mathrm{CH}_{4}$ (Fig. 3).

Our default parameterization of $\mathrm{O}_{2}-\mathrm{O}_{3}-\mathrm{CH}_{4}$ chemistry (C06) is fit over a $p \mathrm{O}_{2}$ range of $10^{-14}$ to $10^{-1}$ bar, a $p \mathrm{CH}_{4}$ range of $10^{-6}$ to $2 \times 10^{-3}$ bar, and a constant high background $p \mathrm{CO}_{2}$ of $10^{-2}$ bar (Claire et al., 2006). We thus truncate the atmospheric lifetime of $\mathrm{CH}_{4}$ at a lower bound of 7.6 years in our default parametrization and provide an alternative parameterization of photochemical $\mathrm{CH}_{4}$ destruction at roughly modern $p \mathrm{O}_{2}$ and $p \mathrm{CO}_{2}$ (SS03) derived from the results of Schmidt and Shindell (2003) for use in more geologically recent, high- $\mathrm{O}_{2}$ atmospheres (Reinhard et al., 2017) (Fig. 4a). Although this parameterized photochemistry

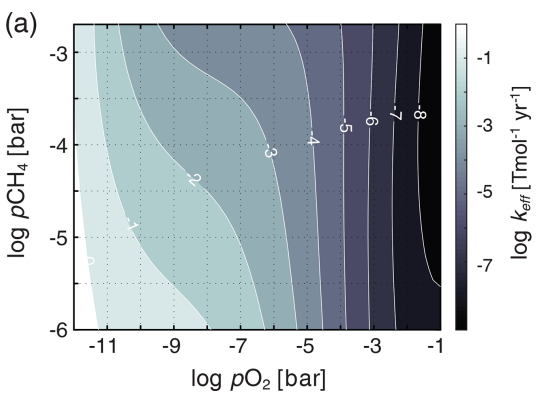

(b)

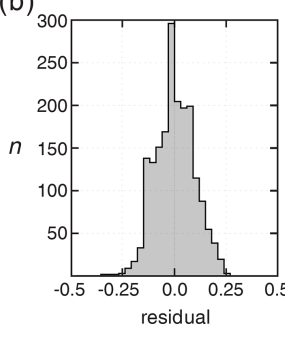

Figure 3. Shown in (a) is the bivariate fit to a suite of 1-D atmospheric photochemical runs for the effective rate constant $\left(k_{\text {eff }}\right)$ parameterizing $\mathrm{O}_{2}-\mathrm{O}_{3}-\mathrm{CH}_{4}$ photochemistry in ATCHEM. Shown in (b) is a frequency distribution of the residuals on $k_{\text {eff }}$ from the underlying photochemical model output.

scheme should represent an improvement in accuracy relative to that implemented in Olson et al. (2016) (see Daines and Lenton, 2016), it is important to point out that a range of factors that might be expected to impact the photochemical destruction rates of $\mathrm{CH}_{4}$ in the atmosphere, including atmospheric $p \mathrm{CO}_{2}$, the atmospheric profile of $\mathrm{H}_{2} \mathrm{O}$, and spectral energy distribution (SED), have not yet been rigorously assessed. Ongoing model developments in ATCHEM are aimed at implementing a more flexible and inclusive photochemical parameterization that will allow for robust use across a wider range of atmospheric compositions and photochemical environments.

As a basic test of our photochemical parameterization, we impose a terrestrial (wetland) flux of $\mathrm{CH}_{4}$ to the atmosphere (balanced by stoichiometric consumption of $\mathrm{CO}_{2}$ and release of $\mathrm{O}_{2}$ ) and allow the oceanic and atmospheric $\mathrm{CH}_{4}$ cycle to spin up for $20 \mathrm{kyr}$. We then compare steady-state atmospheric $p \mathrm{CH}_{4}$ as a function of terrestrial $\mathrm{CH}_{4}$ flux to estimates for the last glacial, preindustrial, and modern periods. Our default parameterization is relatively simple and spans a very wide range in atmospheric $\mathrm{O}_{2}$ and $\mathrm{CH}_{4}$ inventories. Nevertheless, both the default scheme and the alternative parameterization for recent geologic history (and analogous planetary environments), with high- $p \mathrm{O}_{2}$, low- $p \mathrm{CO}_{2}$ atmospheres, accurately reproduce atmospheric $p \mathrm{CH}_{4}$ values given estimated glacial, preindustrial, and modern terrestrial $\mathrm{CH}_{4}$ fluxes (Fig. $4 \mathrm{c}$ ), and both display the predicted saturation of $\mathrm{CH}_{4}$ sinks at elevated atmospheric $\mathrm{CH}_{4}$ observed in more complex photochemical models. We note, however, that the alternative parameterization tends to yield slightly higher atmospheric $p \mathrm{CH}_{4}$ at surface fluxes greater than $\sim 50 \mathrm{Tmol} \mathrm{yr}^{-1}$ (Fig. $4 \mathrm{c}$ ). (In the remainder of the paper, we employ the default (C06) parameterization for atmospheric $\mathrm{O}_{2}-\mathrm{O}_{3}-\mathrm{CH}_{4}$ chemistry and do not discuss the simple high- $p \mathrm{O}_{2}-$ low- $p \mathrm{CO}_{2}$ alternative further.) 

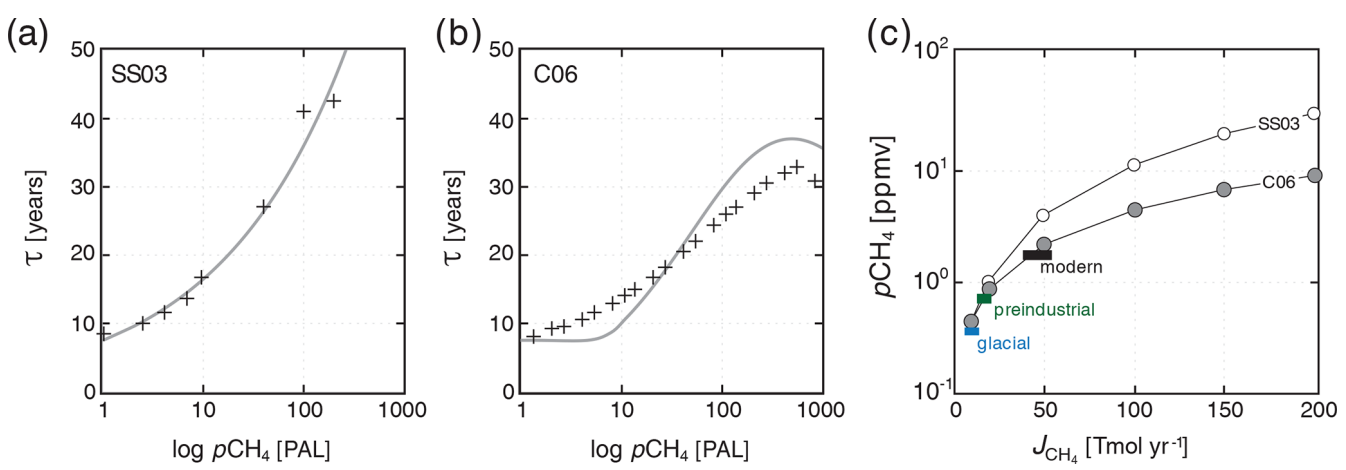

Figure 4. Comparison of steady-state atmospheric $\mathrm{pCH}_{4}$ as a function of terrestrial $\mathrm{CH}_{4}$ flux with modern and more recent estimates. Shown in (a) is an exponential fit to the 2-D photochemistry model of Schmidt and Shindell (2003) (SS03), with individual model runs shown as black crosses. Shown in (b) is a plane through the bivariate fit shown in Fig. 3 (grey curve) compared with the ensemble of 1-D atmospheric photochemical models at $\mathrm{pO}_{2}=0.1$ atm (black crosses; see text). Shown in (c) are steady-state atmospheric $\mathrm{CH}_{4}$ values as a function of imposed terrestrial $\mathrm{CH}_{4}$ flux in our "modern" configuration (circles) compared to estimates for the glacial, preindustrial, and modern $\mathrm{CH}_{4}$ cycles (Kirschke et al., 2013; Bock et al., 2017; Paudel et al., 2016).

\section{Example applications of the new capabilities in the cGENIE model}

\subsection{High- $p \mathrm{O}_{2}$ ("modern") steady state}

We explore a roughly modern steady state with appropriate continental geography and simulated overturning circulation (as in Cao et al., 2009) and initialize the atmosphere with $p \mathrm{O}_{2}, p \mathrm{CO}_{2}$, and $p \mathrm{CH}_{4}$ of $[v / v] 20.95 \%$, $278 \mathrm{ppm}$, and $700 \mathrm{ppb}$, respectively, and with globally uniform oceanic concentrations of $\mathrm{SO}_{4}^{2-}\left(28 \mathrm{mmol} \mathrm{kg}^{-1}\right)$ and $\mathrm{CH}_{4}\left(1 \mathrm{nmol} \mathrm{kg}^{-1}\right)$. We fix globally averaged solar insolation at the modern value $\left(1368 \mathrm{~W} \mathrm{~m}^{-2}\right)$ with seasonally variable forcing as a function of latitude and set radiative forcing for $\mathrm{CO}_{2}$ and $\mathrm{CH}_{4}$ equivalent to preindustrial values in order to isolate the effects of biogeochemistry on steady-state tracer distributions. The model is then spun up for $20 \mathrm{kyr}$ with atmospheric $p \mathrm{O}_{2}$ and $p \mathrm{CO}_{2}$ (and $\delta^{13} \mathrm{C}$ of atmospheric $\mathrm{CO}_{2}$ ) restored to preindustrial values at every time step and with an imposed wetland flux of $\mathrm{CH}_{4}$ to the atmosphere of $20 \mathrm{Tmol} \mathrm{yr}^{-1}$ that has a $\delta^{13} \mathrm{C}$ value of $-60 \%$. Atmospheric $p \mathrm{CH}_{4}$ and all oceanic tracers are allowed to evolve freely.

Surface, benthic, and ocean interior distributions of dissolved oxygen $\left(\mathrm{O}_{2}\right)$, sulfate $\left(\mathrm{SO}_{4}^{2-}\right)$, and methane $\left(\mathrm{CH}_{4}\right)$ are shown in Fig. 5 for our roughly modern simulation. Dissolved $\mathrm{O}_{2}\left(\left[\mathrm{O}_{2}\right]\right)$ approaches air saturation throughout the surface ocean, with a distribution that is largely uniform zonally and with concentrations that increase with latitude as a result of increased solubility at lower temperature near the poles (Fig. 5a). Benthic $\left[\mathrm{O}_{2}\right]$ shows patterns similar to those expected for the modern Earth, with relatively high values in the well-ventilated deep North Atlantic, low values in the deep North Pacific and Indian oceans, and a gradient roughly between air saturation near regions of deep convection in the high-latitude Atlantic and much lower values in the tropical and northern Pacific (Fig. 5d). Distributions of $\left[\mathrm{O}_{2}\right]$ in the ocean interior are similar to those of the modern Earth (Fig. 5g) with oxygen minimum zones (OMZs) at intermediate depths underlying highly productive surface waters, particularly in association with coastal upwelling at low latitudes.

Concentrations of dissolved $\mathrm{SO}_{4}^{2-}\left(\left[\mathrm{SO}_{4}^{2-}\right]\right)$ are largely invariant throughout the ocean, consistent with its expected conservative behavior in the modern ocean as one of the most abundant negative ions in seawater (Fig. 5). Slightly higher concentrations in both surface and benthic fields are seen in association with outflow from the Mediterranean and are driven by evaporative concentration (Fig. 5b). Benthic $\left[\mathrm{SO}_{4}^{2-}\right]$ distributions show some similarity to those of $\left[\mathrm{O}_{2}\right]$ (Fig. 5e), though again the differences are very small relative to the overall prescribed initial tracer inventory of $28 \mathrm{mmol} \mathrm{kg}^{-1}$ and disappear almost entirely when salinitynormalized (not shown). In the ocean interior, $\left[\mathrm{SO}_{4}^{2-}\right]$ is largely spatially invariant with a value of approximately $28 \mathrm{mmol} \mathrm{kg}^{-1}$ (Fig. 5h).

Dissolved $\mathrm{CH}_{4}$ concentrations $\left(\left[\mathrm{CH}_{4}\right]\right)$ in the surface and shallow subsurface ocean are much more variable but typically on the order of $\sim 1-2 \mathrm{nmol} \mathrm{kg}^{-1}$, with slightly elevated concentrations just below the surface, both of which are consistent with observations from the modern ocean (Reeburgh, 2007; Scranton and Brewer, 1978). The benthic $\left[\mathrm{CH}_{4}\right]$ distribution shows locally elevated values up to $\sim 300-400 \mathrm{nmol} \mathrm{kg}^{-1}$ in shallow regions of the tropical and northern Pacific and the Indian oceans (Fig. 5f), which is also broadly consistent with observations from shallow marine environments with active benthic $\mathrm{CH}_{4}$ cycling (Jayakumar et al., 2001). Within the ocean interior, dissolved $\mathrm{CH}_{4}$ can accumulate in the water column in excess of $\sim 100 \mathrm{nmol} \mathrm{kg}^{-1}$ in association with relatively low- $\mathrm{O}_{2}$ conditions at intermediate depths, with zonally averaged values as high as $\sim 70 \mathrm{nmol} \mathrm{kg}^{-1}$ but more typically in the range of $\sim 20$ 

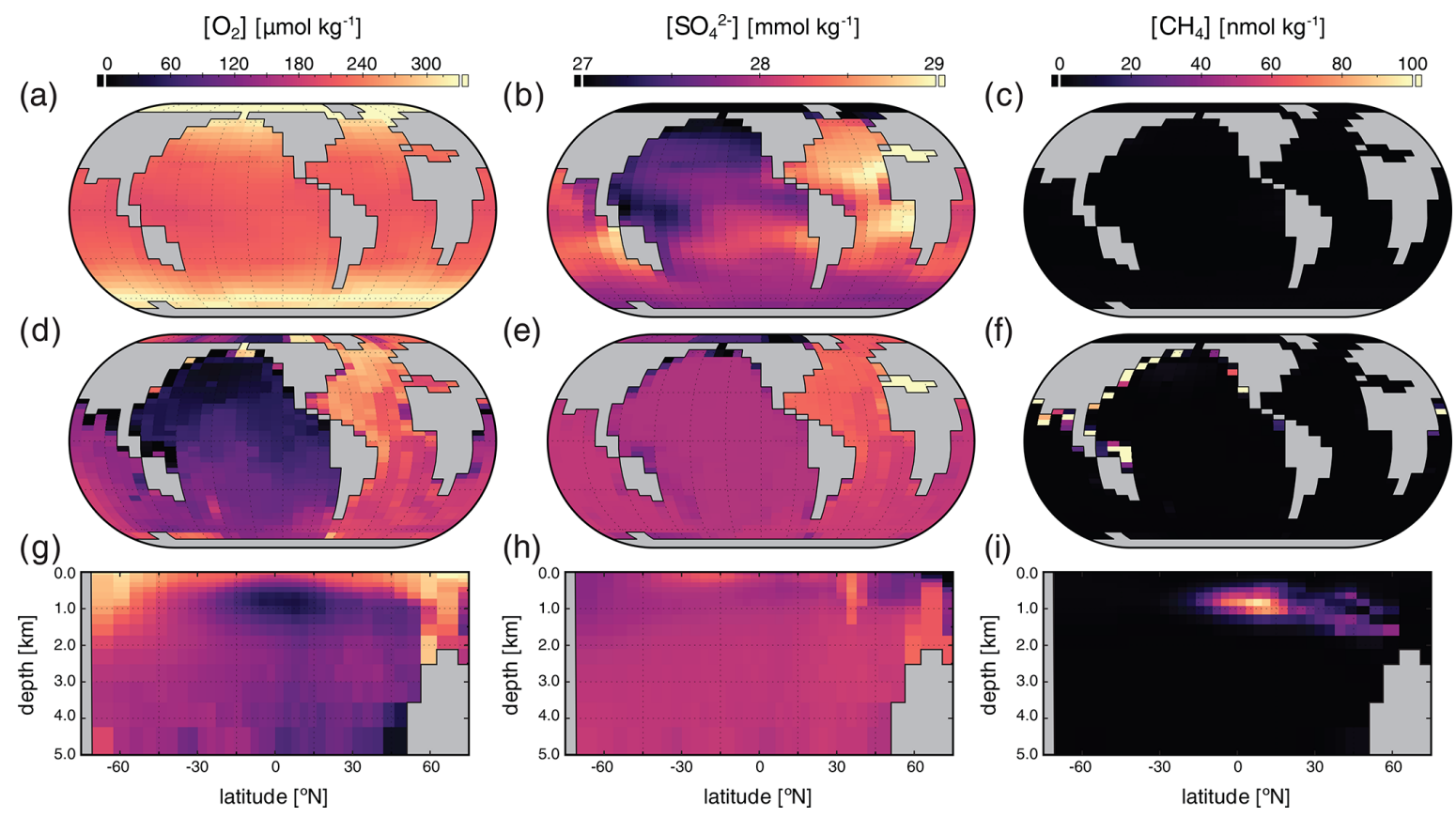

Figure 5. Tracer distributions in surface (a-c) and benthic (d-f) grid cells and in the zonally averaged ocean interior $(\mathbf{g}-\mathbf{i})$ for $\mathrm{O}_{2}(\mathbf{a}, \mathbf{d}, \mathbf{g})$, $\mathrm{SO}_{4}^{2-}(\mathbf{b}, \mathbf{e}, \mathbf{h})$, and $\mathrm{CH}_{4}(\mathbf{c}, \mathbf{f}, \mathbf{i})$ in our "modern" configuration. Note the different concentration units for each tracer.

$40 \mathrm{nmol} \mathrm{kg}^{-1}$ (Fig. 5i). These concentrations are comparable to those observed locally in low- $\mathrm{O}_{2}$ regions of the modern ocean (Sansone et al., 2001; Chronopoulou et al., 2017; Thamdrup et al., 2019).

The major metabolic fluxes within the ocean's microbial $\mathrm{CH}_{4}$ cycle for our "modern" configuration are shown in Fig. 6. Methanogenesis is focused in regions characterized by relatively low $\left[\mathrm{O}_{2}\right]$ and is particularly vigorous in the eastern tropical Pacific, the North Pacific, and the Indian Ocean (Fig. 6a). The highest zonally averaged rates of methanogenesis are observed in northern tropical and subtropical latitudes and are focused at a depth of $\sim 1 \mathrm{~km}$ (Fig. 6d). Rates of microbial $\mathrm{CH}_{4}$ consumption are generally spatially coupled to rates of methanogenesis, both in a column-integrated sense (Fig. 6b, c) and in the zonal average (Fig. 6e, f). This is particularly true for AOM, the rates of which are highest within the core of elevated methanogenesis rates observed in the northern subtropics. Zonally averaged AOM rates of $\sim 10$ $15 \mathrm{nmol} \mathrm{kg}^{-1} \mathrm{~d}^{-1}$ compare well with field measurements of AOM within oceanic OMZs (Thamdrup et al., 2019). In general, the bulk of $\mathrm{CH}_{4}$ produced via microbial methanogenesis is consumed via AOM, either near the seafloor or within the ocean interior.

\subsection{Low- $p \mathrm{O}_{2}$ ("ancient") steady state}

Next, we explore a low- $p \mathrm{O}_{2}$ steady state, similar to the Proterozoic Earth (Reinhard et al., 2017) but played out in a modern continental configuration and overturning circulation, by initializing the atmosphere with $p \mathrm{O}_{2}, p \mathrm{CO}_{2}$, and $p \mathrm{CH}_{4}$ of $[v / v] 2.1 \times 10^{-4}$ atm (equivalent to a value $10^{-3}$ times the present atmospheric level, PAL), $278 \mathrm{ppm}$, and $500 \mathrm{ppm}$, respectively, as well as globally uniform oceanic concentrations of $\mathrm{SO}_{4}^{2-}\left(280 \mu \mathrm{mol} \mathrm{kg}{ }^{-1}\right)$ and $\mathrm{CH}_{4}$ $\left(50 \mu \mathrm{mol} \mathrm{kg}{ }^{-1}\right)$. We again fix globally averaged solar insolation at the modern value $\left(1368 \mathrm{~W} \mathrm{~m}^{-2}\right)$, with seasonally variable forcing as a function of latitude, and set radiative forcing for $\mathrm{CO}_{2}$ and $\mathrm{CH}_{4}$ equivalent to the modern preindustrial state in order to isolate the effects of biogeochemistry on steady-state tracer distributions. The model is then spun up for $20 \mathrm{kyr}$ with atmospheric $p \mathrm{O}_{2}$ and $p \mathrm{CO}_{2}$ (and $\delta^{13} \mathrm{C}$ of atmospheric $\mathrm{CO}_{2}$ ) restored to the initial values specified above at every time step, with an imposed "geologic" flux of $\mathrm{CH}_{4}$ to the atmosphere of $3 \mathrm{Tmol} \mathrm{yr}^{-1}$ at a $\delta^{13} \mathrm{C}$ value of $-60 \%$. Atmospheric $p \mathrm{CH}_{4}$ and all oceanic tracers are allowed to evolve freely.

Surface, benthic, and ocean interior distributions of $\left[\mathrm{O}_{2}\right]$, $\left[\mathrm{SO}_{4}^{2-}\right]$, and $\left[\mathrm{CH}_{4}\right]$ are shown in Fig. 7 for our low- $p \mathrm{O}_{2}$ simulation. Dissolved $\mathrm{O}_{2}$ concentrations are now extremely heterogeneous throughout the surface ocean, ranging over an order of magnitude from less than 1 to over $10 \mu \mathrm{mol} \mathrm{kg}^{-1}$, with concentrations that are regionally well in excess of air saturation at the prescribed $p \mathrm{O}_{2}$ of $2.1 \times 10^{-4}$ atm (Fig. 7a). Previous studies have shown that these features are not unexpected at very low atmospheric $p \mathrm{O}_{2}$ (Olson et al., 2013; Reinhard et al., 2016). We note, however, that the distribution and maximum $\left[\mathrm{O}_{2}\right]$ in our low- $p \mathrm{O}_{2}$ simulation are both somewhat different from those presented in Olson et al. (2013) and Reinhard et al. (2016). We attribute this primarily to the differ- 
(a)

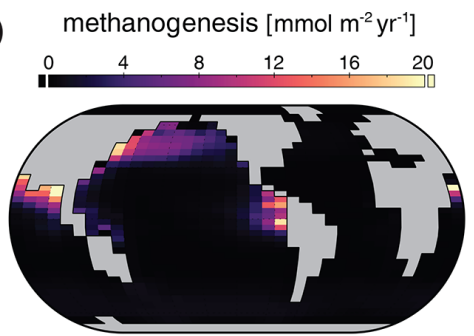

(d) methanogenesis [nmol kg $\mathrm{ng}^{-1}$ ]
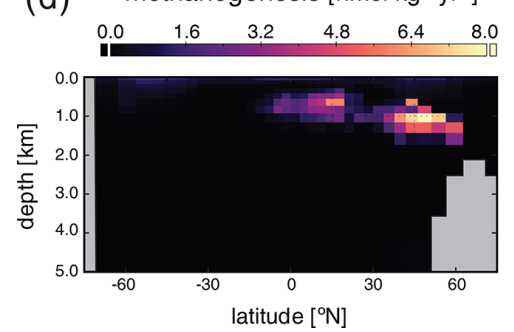

(b)

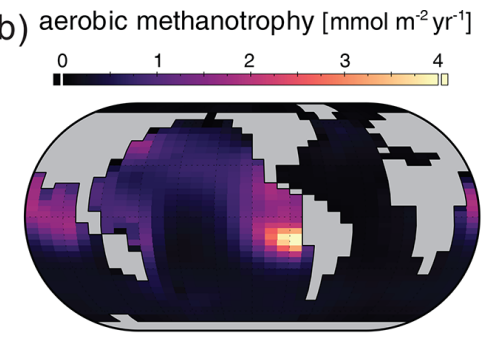

(e)

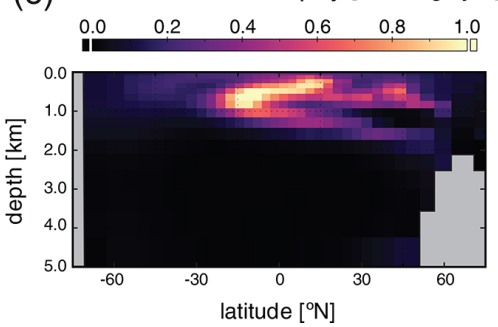

(c)

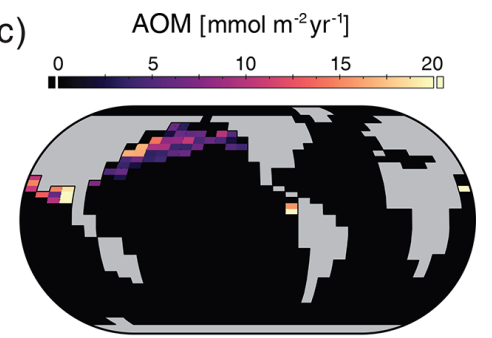

(f)

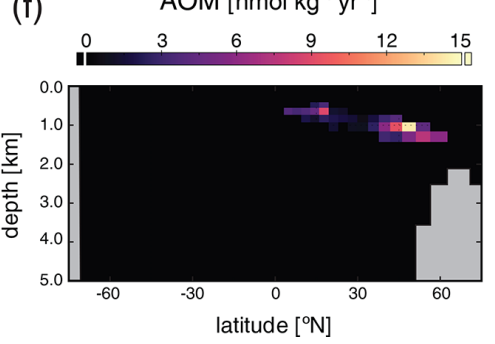

Figure 6. Major biological fluxes in the marine methane cycle for our "modern" configuration. Panels show column integrated (a-c) and zonally averaged (d-f) rates of methanogenesis, aerobic methanotrophy, and anaerobic methane oxidation (AOM) in the ocean interior.

ent parameterizations of primary production in the surface ocean. In the biogeochemical configuration of cGENIE we adopt here, we allow rates of photosynthesis to scale more directly with available $\mathrm{PO}_{4}^{3-}$ than is the case in these previous studies (Eq. 3), which allows for higher rates of oxygen production in regions of deep mixing and relatively intense organic matter recycling below the photic zone (Fig. 7a). In any case, as in previous examinations of surface $\left[\mathrm{O}_{2}\right]$ dynamics at low atmospheric $p \mathrm{O}_{2}$ (Olson et al., 2013; Reinhard et al., 2016), our regional $\left[\mathrm{O}_{2}\right]$ patterns still generally track the localized balance between photosynthetic $\mathrm{O}_{2}$ release and consumption through respiration and reaction with inorganic reductants, rather than temperature-dependent solubility patterns (Fig. 5a). Within the ocean interior, $\mathrm{O}_{2}$ is consumed within the upper few hundred meters and is completely absent in benthic settings (Fig. 7d, g).

In our low- $p \mathrm{O}_{2}$ simulations we initialize the ocean with a globally uniform $\left[\mathrm{SO}_{4}^{2-}\right]$ of $280 \mu \mathrm{mol} \mathrm{kg}{ }^{-1}$, under the premise that the marine $\mathrm{SO}_{4}^{2-}$ inventory should scale positively with atmospheric $p \mathrm{O}_{2}$. With this much lower initial $\mathrm{SO}_{4}^{2-}$ inventory (i.e., $10^{2}$ times less than the modern ocean), steady-state $\left[\mathrm{SO}_{4}^{2-}\right]$ distributions are significantly more heterogeneous than in the modern, high- $p \mathrm{O}_{2}$ case (Fig. 7). Ocean $\left[\mathrm{SO}_{4}^{2-}\right]$ is approximately homogeneous spatially in surface waters, even with a significantly reduced seawater inventory (Fig. 7a), but is strongly variable within the ocean interior (Fig. 7e, h). Indeed, in our low- $p \mathrm{O}_{2}$ simulations $\mathrm{SO}_{4}^{2-}$ serves as the principal oxidant for organic matter remineralization in the ocean interior, with the result that its distribution effectively mirrors that of $\left[\mathrm{O}_{2}\right]$ in the modern case in both spatial texture and overall magnitude (compare Fig. 7e, $\mathrm{h}$ with Fig. 5d, g). Dissolved $\mathrm{SO}_{4}^{2-}$ in this simulation never drops to zero, a consequence of our initial $280 \mu \mathrm{mol} \mathrm{kg}$ concentration of $\mathrm{SO}_{4}^{2-}$ representing the oxidative potential of $560 \mu \mathrm{mol} \mathrm{kg}{ }^{-1}$ of $\mathrm{O}_{2}$, some 3 times higher than the mean $\left[\mathrm{O}_{2}\right]$ value in the modern ocean interior $\left(\sim 170 \mu \mathrm{mol} \mathrm{kg}^{-1}\right)$.

Dissolved $\mathrm{CH}_{4}$ concentrations in the surface and shallow subsurface ocean are variable but much higher than in our modern simulations, typically on the order of $\sim 1$ $2 \mu \mathrm{mol} \mathrm{kg}^{-1}$ (Fig. 7c). The benthic [ $\left.\mathrm{CH}_{4}\right]$ distribution shows concentrations up to $\sim 8 \mu \mathrm{mol} \mathrm{kg}{ }^{-1}$, with concentrations in excess of $1 \mu \mathrm{mol} \mathrm{kg}^{-1}$ pervasively distributed across the seafloor. In general, the benthic $\left[\mathrm{CH}_{4}\right]$ distribution inversely mirrors that of $\left[\mathrm{SO}_{4}^{2-}\right]$ (Fig. 7f), which results from the fact that in the low- $p \mathrm{O}_{2}$ case $\mathrm{SO}_{4}^{2-}$ again serves as the principal oxidant of methane. Concentrations of $\mathrm{CH}_{4}$ in the ocean interior can approach $\sim 10 \mu \mathrm{mol} \mathrm{kg}^{-1}$ but in the zonal average are typically less than $5 \mu \mathrm{molkg}^{-1}$ (Fig. 7i). Overall, the oceanic $\mathrm{CH}_{4}$ inventory increases dramatically in the low$p \mathrm{O}_{2}$ case relative to the modern simulation, from $\sim 4.5 \mathrm{Tmol}$ $\mathrm{CH}_{4}$ to $\sim 1900 \mathrm{Tmol} \mathrm{CH}_{4}$.

The major metabolic fluxes within the ocean's microbial $\mathrm{CH}_{4}$ cycle for our "ancient" configuration are shown in Fig. 8. Column-integrated rates of microbial methanogenesis are greater than in the high- $p \mathrm{O}_{2}$ case by up to a factor of $\sim 10^{2}$ (Fig. 8a), with methanogenesis also showing a much broader areal distribution. Within the ocean interior, rates of methanogenesis are most elevated in the upper $\sim 1 \mathrm{~km}$ (Fig. 8d) as a consequence of elevated rates of organic carbon remineralization combined with a virtual absence of dissolved $\mathrm{O}_{2}$ beneath the upper $\sim 200 \mathrm{~m}$. Rates of aerobic methanotrophy, which is effectively absent in the ocean interior (Fig. 8e), are elevated relative to those observed in the high- $p \mathrm{O}_{2}$ simulation by less than an order of magnitude and are concentrated in the tropical surface ocean near the equatorial divergence (Fig. 8b). In contrast, AOM is 

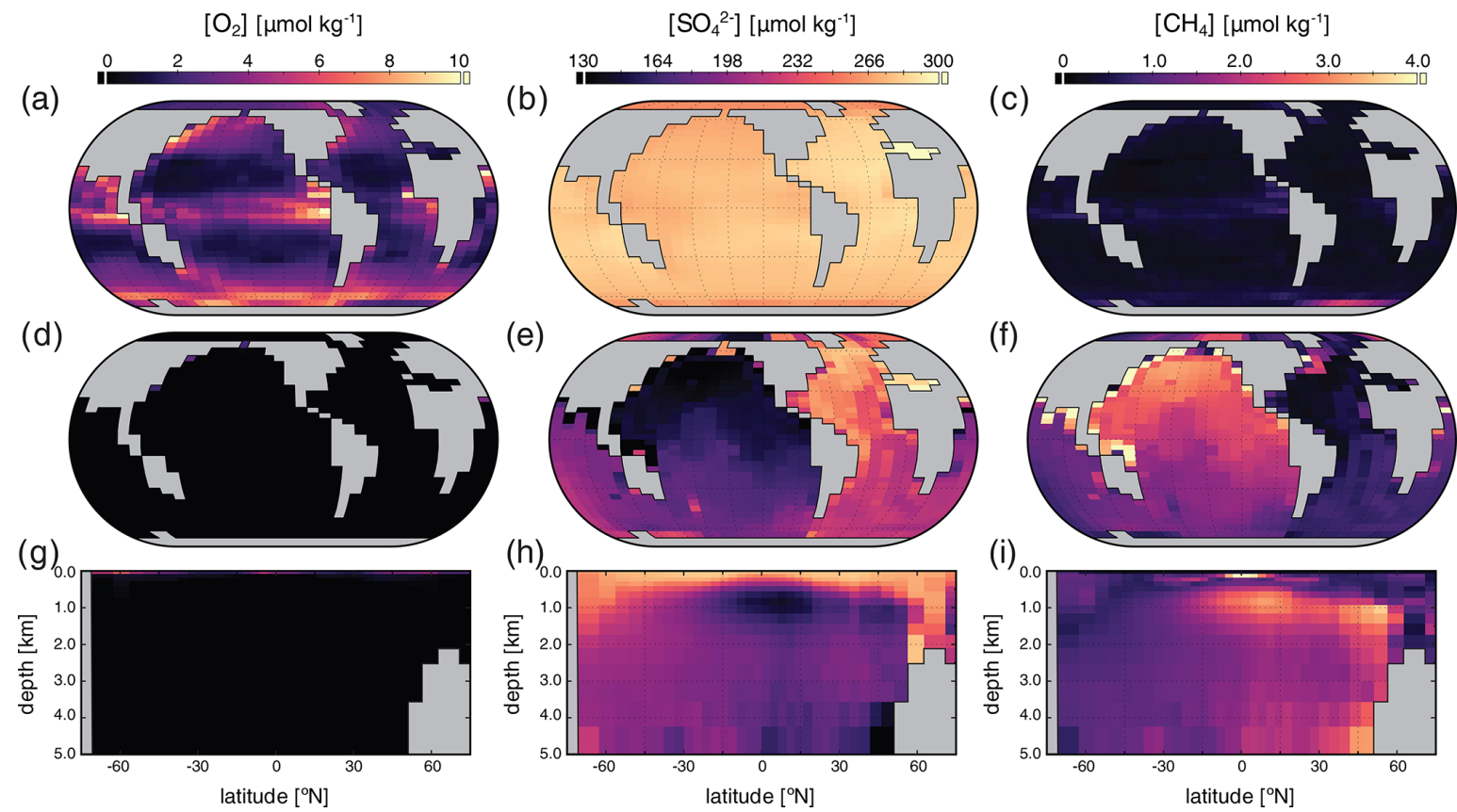

Figure 7. Tracer distributions in surface $(\mathbf{a}-\mathbf{c})$ and benthic $(\mathbf{d}-\mathbf{f})$ grid cells and in the zonally averaged ocean interior $(\mathbf{g}-\mathbf{i})$ for $\mathrm{O}_{2}(\mathbf{a}, \mathbf{d}$, $\mathbf{g}), \mathrm{SO}_{4}^{2-}(\mathbf{b}, \mathbf{e}, \mathbf{h})$, and $\mathrm{CH}_{4}(\mathbf{c}, \mathbf{f}, \mathbf{i})$ in our "ancient" configuration (see text). Note the different concentration units for each tracer and the differing scales relative to Fig. 5.

strongly coupled spatially to microbial methanogenesis, with rates that are often well over $\sim 10^{2}$ times higher than those observed in the high- $p \mathrm{O}_{2}$ case (Fig. 8c, f). Once again, AOM dominates the consumption of $\mathrm{CH}_{4}$ produced in the ocean interior and is extremely effective at reducing $\mathrm{CH}_{4}$ fluxes to the atmosphere. Despite a significant increase in overall oceanic $\mathrm{CH}_{4}$ burden relative to our high- $p \mathrm{O}_{2}$ simulation (see above and Fig. 7i), atmospheric $p \mathrm{CH}_{4}$ increases only modestly from $\sim 0.8 \mathrm{ppm}$ to $6 \mathrm{ppm}[v / v]$, equivalent to an additional radiative forcing of only $\sim 2 \mathrm{~W} \mathrm{~m}^{-2}$, due to efficient microbial consumption in the upper ocean.

\subsection{Atmospheric carbon injection}

To illustrate the capabilities of the model in exploring the time-dependent (perturbation) behavior of the $\mathrm{CH}_{4}$ cycle, we perform a simple carbon injection experiment in which $3000 \mathrm{PgC}$ is injected directly into the atmosphere either as $\mathrm{CH}_{4}$ or as $\mathrm{CO}_{2}$, starting from our modern steady state. The injection is spread over 1000 years, with an instantaneous initiation and termination of carbon input to the atmosphere. This is meant only to illustrate the time-dependent behavior of the model in the face of an idealized carbon cycle perturbation, rather than to evaluate any particular scenario for explaining previous climate transients in Earth's history. However, the magnitude and duration of this carbon injection, corresponding to $3 \mathrm{PgC} \mathrm{yr}^{-1}$, are meant to roughly mimic the upper end of estimates for the Paleocene-Eocene Thermal Maximum (PETM), a transient global warming event at $\sim 56 \mathrm{Ma}$ hypothesized to have been driven by emissions of $\mathrm{CO}_{2}$ and/or $\mathrm{CH}_{4}$ (Kirtland Turner, 2018). This flux is much lower than the current anthropogenic carbon input of $\sim 10 \mathrm{PgC} \mathrm{yr}^{-1}$ (Ciais et al., 2013). For simplicity, and because we focus on only the first 3000 years following carbon injection, we treat the ocean-atmosphere system as closed, with the result that all injected carbon ultimately accumulates within the ocean and atmosphere rather than being removed through carbonate compensation and silicate weathering.

Following a carbon release to the atmosphere in the form of $\mathrm{CH}_{4}$, there is an immediate and significant increase in atmospheric $p \mathrm{CH}_{4}$ to values greater than $10 \mathrm{ppmv}$, followed by a gradual increase to a maximum of $\sim 12 \mathrm{ppmv}$ throughout the duration of the $\mathrm{CH}_{4}$ input (Fig. 9a). Much of this methane is exchanged with the surface ocean and consumed by aerobic methanotrophy, while some is photochemically oxidized directly in the atmosphere, both of which lead to a significant but delayed increase in atmospheric $p \mathrm{CO}_{2}$ (Fig. 9b). This increase in atmospheric $p \mathrm{CH}_{4}$ and $p \mathrm{CO}_{2}$ leads to an increase in global average surface air temperature (SAT) of $\sim 7^{\circ} \mathrm{C}$ (Fig. 9d) and an increase in mean ocean temperature (MOT) of $\sim 2{ }^{\circ} \mathrm{C}$ (Fig. 9e), along with significant acidification of the surface ocean (Fig. 9c).

The increase in atmospheric $p \mathrm{CO}_{2}$ and drop in ocean $\mathrm{pH}$ are nearly identical if we instead inject the carbon as $\mathrm{CO}_{2}$ rather than $\mathrm{CH}_{4}$ (Fig. 9b, c). However, when carbon is injected as $\mathrm{CH}_{4}$, there is an additional transient increase in global surface air temperature of $\sim 2{ }^{\circ} \mathrm{C}$ and roughly $0.5^{\circ} \mathrm{C}$ 
(a)

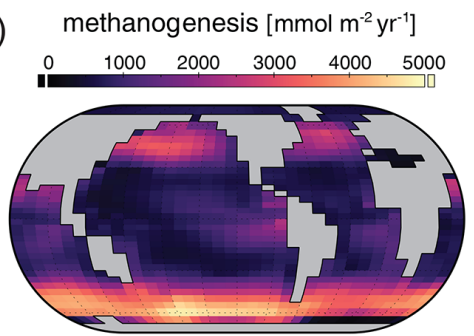

(d) methanogenesis [nmol kg $\left.{ }^{-1} \mathrm{yr}^{-1}\right]$
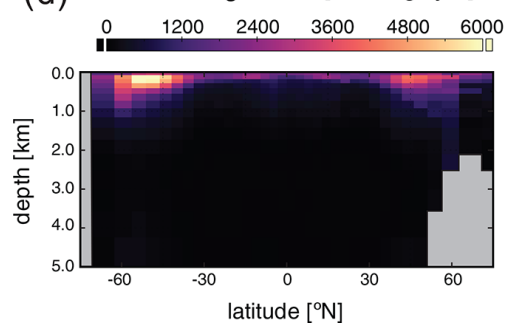

(b)

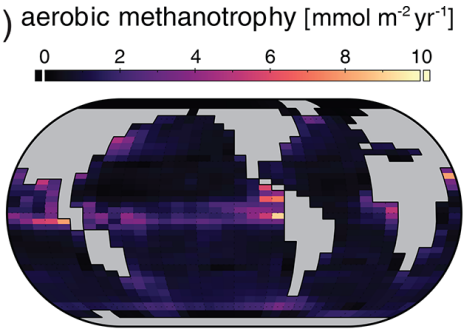

(e) aerobic methanotrophy [nmol kg-1 $\left.\mathrm{yr}^{-1}\right]$

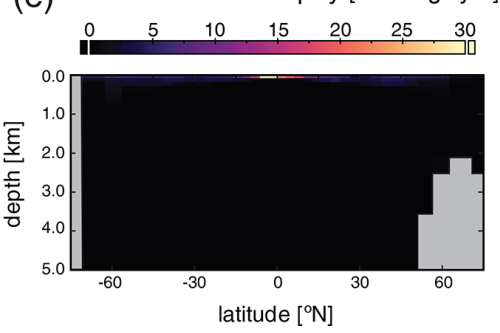

(c)

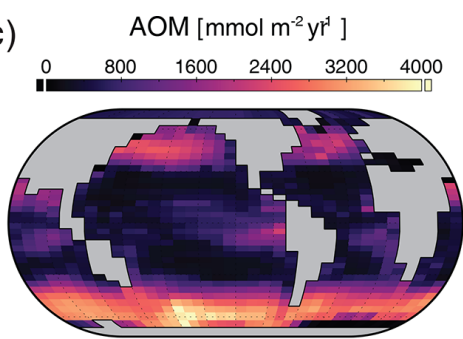

(f)

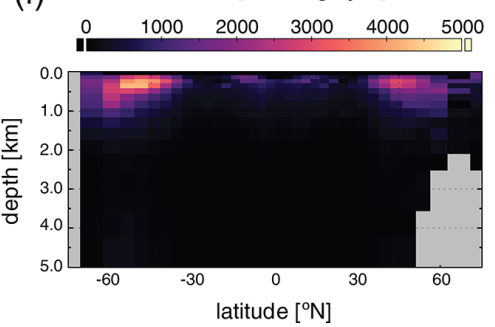

Figure 8. Major biological fluxes in the marine methane cycle for our "ancient" configuration. Panels show column-integrated (a-c) and zonally averaged (d-f) rates of methanogenesis, aerobic methanotrophy, and anaerobic methane oxidation (AOM) in the ocean interior.
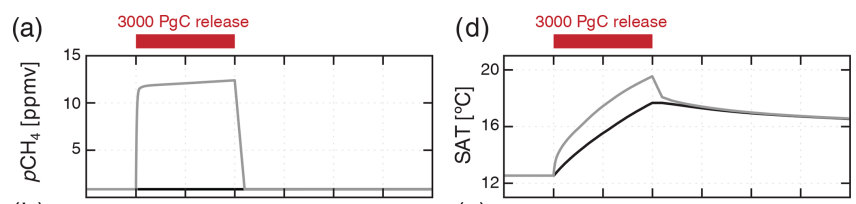

(b)
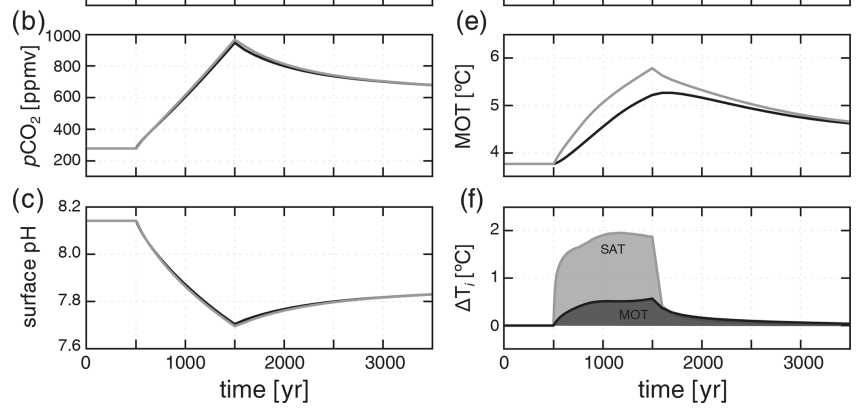

Figure 9. Response to a $3000 \mathrm{PgC}$ release directly to the atmosphere spread over 1000 years, assuming carbon is injected as either $\mathrm{CH}_{4}$ or $\mathrm{CO}_{2}$. Atmospheric $p \mathrm{CH}_{4}(\mathbf{a}), p \mathrm{CO}_{2}(\mathbf{b})$, mean surface ocean $\mathrm{pH}(\mathbf{c})$, mean surface air temperature (SAT; d), and mean ocean temperature (MOT; e) are shown for a $\mathrm{CH}_{4}$ injection (grey) and a $\mathrm{CO}_{2}$ injection (black). Panel (f) shows the difference in SAT and MOT between the $\mathrm{CH}_{4}$ and $\mathrm{CO}_{2}$ injection scenarios $\left(\Delta T_{\mathrm{i}}=T_{\mathrm{CH}_{4}, \mathrm{i}}\right.$ $-T_{\mathrm{CO}_{2}, \mathrm{i}}$ ) through time.

of additional whole-ocean warming for the same carbon input and duration (Fig. 9f). This results from the fact that, mole for mole, $\mathrm{CH}_{4}$ is a much more powerful greenhouse gas than is $\mathrm{CO}_{2}$, and oxidation of $\mathrm{CH}_{4}$ to $\mathrm{CO}_{2}$ is not instantaneous during the carbon release interval. Combined, these factors result in a disequilibrium situation in which a proportion of carbon released to the atmosphere remains in the form of $\mathrm{CH}_{4}$ rather than $\mathrm{CO}_{2}$, providing an enhancement of warming, especially during the duration of carbon input. This warming enhancement should be considered in past events during which $\mathrm{CH}_{4}$ release is suspected as a key driver of warming. For instance, additional warming due to $\mathrm{CH}_{4}$ forcing may help explain the apparent discrepancy between the amount of warming reconstructed by proxy records and proposed carbon forcing during the PETM (Zeebe et al., 2009).

\subsection{Atmospheric $\mathrm{pCH}_{4}$ on the early Earth}

Using our low- $p \mathrm{O}_{2}$ steady state as a benchmark case (Sect. 5.2), we briefly explore the sensitivity of atmospheric $p \mathrm{CH}_{4}$ to a subset of model variables. All model ensembles are initially configured with globally homogeneous marine $\mathrm{SO}_{4}^{2-}$ and $\mathrm{CH}_{4}$ inventories, as well as a background geologic $\mathrm{CH}_{4}$ flux of $3 \mathrm{Tmol} \mathrm{yr}^{-1}$, and are spun up for $20 \mathrm{kyr}$ with a fixed $p \mathrm{O}_{2}$ and $p \mathrm{CO}_{2}$. We report atmospheric $p \mathrm{CH}_{4}$ from the final model year. Our purpose here is not to be exhaustive or to elucidate any particular period of Earth's history, but to demonstrate some of the major factors controlling the atmospheric abundance of $\mathrm{CH}_{4}$ on a low-oxygen Earth-like planet. We present results from individual sensitivity ensembles from our benchmark low- $p \mathrm{O}_{2}$ case over the following parameter ranges: (1) atmospheric $\mathrm{pO}_{2}$ between $10^{-4}$ and $10^{-1}$ times the present atmospheric level (PAL), equivalent to roughly $2 \times 10^{-5}$ and $2 \times 10^{-2}$ atm, respectively; (2) initial marine $\mathrm{SO}_{4}^{2-}$ inventories corresponding to globally uniform seawater concentrations between 0 and $1000 \mu \mathrm{mol} \mathrm{kg}^{-1}$; and (3) biological energy quanta (BEQ) for anaerobic methane oxidation between 5 and $30 \mathrm{~kJ} \mathrm{~mol}^{-1}$.

Results for our low- $p \mathrm{O}_{2}$ sensitivity ensembles are shown in Fig. 10. We find a similar sensitivity of atmospheric $p \mathrm{CH}_{4}$ to atmospheric $p \mathrm{O}_{2}$ to that observed by Olson et al. (2016). In particular, atmospheric $\mathrm{CH}_{4}$ abundance initially increases 
as atmospheric $p \mathrm{O}_{2}$ drops below modern values to roughly $2 \%-3 \%$ PAL, after which decreasing $p \mathrm{O}_{2}$ causes $p \mathrm{CH}_{4}$ to drop. This behavior is well-known from previous 1-D photochemical model analysis and arises principally from increasing production of $\mathrm{OH}$ via water vapor photolysis as shielding of $\mathrm{H}_{2} \mathrm{O}$ by ozone $\left(\mathrm{O}_{3}\right)$ decreases at low atmospheric $p \mathrm{O}_{2}$ (Pavlov et al., 2003; Claire et al., 2006; Goldblatt et al., 2006). However, peak atmospheric $p \mathrm{CH}_{4}$ is significantly reduced in our models relative to those of Olson et al. (2016). For example, at an "optimal" atmospheric $p \mathrm{O}_{2}$ of $\sim 2.5 \%$ PAL, Olson et al. (2016) predict a steady-state atmospheric $p \mathrm{CH}_{4}$ of $\sim 35 \mathrm{ppmv}$, while we predict a value of $\sim 10 \mathrm{ppmv}$ (Fig. 10a). This difference can be attributed to our updated $\mathrm{O}_{2}-\mathrm{O}_{3}-\mathrm{CH}_{4}$ photochemistry parameterization together with a significant upward revision in the rate constant for aerobic methanotrophy. Nevertheless, our results strongly reinforce the arguments presented in Olson et al. (2016) and, taken at face value, further marginalize the role of $\mathrm{CH}_{4}$ as a significant climate regulator at steady state during most of the Proterozoic eon (between $\sim 2.5$ and $0.5 \mathrm{Ga}$ ).

Atmospheric $\mathrm{CH}_{4}$ abundance is also strongly sensitive to the marine $\mathrm{SO}_{4}^{2-}$ inventory (Fig. 10b). The scaling we observe between the initial $\mathrm{SO}_{4}^{2-}$ inventory and steady-state atmospheric $p \mathrm{CH}_{4}$ is very similar to that reported by Olson et al. (2016), with a sharp drop in the marine $\mathrm{CH}_{4}$ inventory and atmospheric $\mathrm{CH}_{4}$ abundance as marine $\mathrm{SO}_{4}^{2-}$ drops below $\sim 100 \mu \mathrm{mol} \mathrm{kg}^{-1}$ (Fig. 10b). The implication is that for most of Earth's history anaerobic oxidation of $\mathrm{CH}_{4}$ in the ocean interior has served as an important inhibitor of $\mathrm{CH}_{4}$ fluxes from the ocean biosphere. However, during much of the Archean eon (between 4.0 and $2.5 \mathrm{Ga}$ ), sulfur isotope analysis indicates that marine $\mathrm{SO}_{4}^{2-}$ concentrations may instead have been on the order of $\sim 1-10 \mu \mathrm{mol} \mathrm{kg}^{-1}$ (Crowe et al., 2014), while atmospheric $p \mathrm{O}_{2}$ would also have been much lower than the values examined here (Pavlov and Kasting, 2002). The impact of the ocean biosphere and redox chemistry on atmospheric $p \mathrm{CH}_{4}$ and Earth's climate system may thus have been much more important prior to $\sim 2.5$ billion years ago.

Atmospheric $\mathrm{CH}_{4}$ is significantly impacted by the value chosen for the biological energy quantum (BEQ). With all other parameters held constant, we observe an increase in steady-state atmospheric $p \mathrm{CH}_{4}$ from $\sim 7$ to $\sim 25 \mathrm{ppmv}$ when increasing the BEQ value from 20 to $30 \mathrm{~kJ} \mathrm{~mol}^{-1}$ (Fig. 10c). This effect is mediated primarily by the importance of anaerobic methanotrophy when atmospheric $p \mathrm{O}_{2}$ is low and the ocean interior is pervasively reducing. The standard free energy of AOM is of the same order of magnitude as the BEQ (see above), which elevates the importance of thermodynamic drive in controlling global rates of AOM. We would expect this effect to be much less important when aerobic methanotrophy is the predominant $\mathrm{CH}_{4}$-consuming process within the ocean biosphere, as the standard free energy of this metabolism is over an order of magnitude greater than typical BEQ values for microbial metabolism (e.g., Hoehler, 2004). In any case, our results suggest that the role of thermodynamics should be borne in mind in scenarios for which AOM is an important process in the $\mathrm{CH}_{4}$ cycle and seawater $\left[\mathrm{SO}_{4}^{2-}\right]$ is relatively low.

\section{Discussion and conclusions}

The global biogeochemical cycling of $\mathrm{CH}_{4}$ is central to the climate and redox state of planetary surface environments and responds to the internal dynamics of other major biogeochemical cycles across a very wide range of spatial and temporal scales. There is thus strong impetus for the ongoing development of a spectrum of models designed to explore planetary $\mathrm{CH}_{4}$ cycling, from simple box models to more computationally expensive 3-D models with dynamic and interactive ocean circulation. Our principal goal here is the development of a mechanistically realistic but simple and flexible representation of $\mathrm{CH}_{4}$ biogeochemical cycling in Earth's ocean-atmosphere system, with the hope that this can be further developed to explore steady-state and time-dependent changes to the global $\mathrm{CH}_{4}$ cycle in Earth's past and future and ultimately to constrain $\mathrm{CH}_{4}$ cycling dynamics on Earthlike planets beyond our solar system.

To accomplish this, we have refined the organic carbon remineralization scheme in the cGENIE Earth system model to reflect the impact of anaerobic organic matter recycling in sinking aggregates within oxygenated waters and to include the carbon cycling and isotopic effects of microbial $\mathrm{CH}_{4}$ production. We have also incorporated revised schemes for microbial $\mathrm{CH}_{4}$ consumption that include both kinetic and thermodynamic constraints, and we have updated the parameterized atmospheric $\mathrm{O}_{2}-\mathrm{O}_{3}-\mathrm{CH}_{4}$ photochemistry to improve accuracy and for use across a wider range of atmospheric $p \mathrm{O}_{2}$ values than explored in previous work. Simulations of roughly modern (high- $\mathrm{O}_{2}$ ) and Proterozoic (low- $\mathrm{O}_{2}$ ) Earth system states demonstrate that the model effectively reproduces the first-order features of the modern oceanatmosphere $\mathrm{CH}_{4}$ cycle and can be effectively implemented across a wide range of atmospheric $\mathrm{O}_{2}$ partial pressures and marine $\mathrm{SO}_{4}^{2-}$ concentrations. In addition, our results strongly reinforce the conclusions of Olson et al. (2016) for the Proterozoic Earth system, while going beyond this to posit that the thermodynamics of anaerobic $\mathrm{CH}_{4}$ consumption may have been important in regulating atmospheric $\mathrm{CH}_{4}$ abundance during the Archean. Finally, our simulation of PETMlike carbon injection demonstrates the importance of explicitly considering $\mathrm{CH}_{4}$ radiative forcing during transient warming events in Earth history.

We suggest that ongoing and future development work should focus on the following: (1) more rigorous tuning of organic carbon remineralization and $\mathrm{CH}_{4}$ production and consumption schemes based on data fields from the modern ocean; (2) development and implementation of a more 
(a)

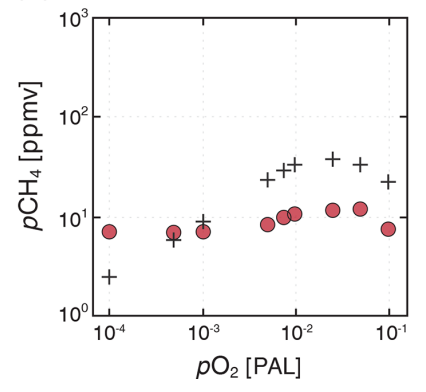

(b)

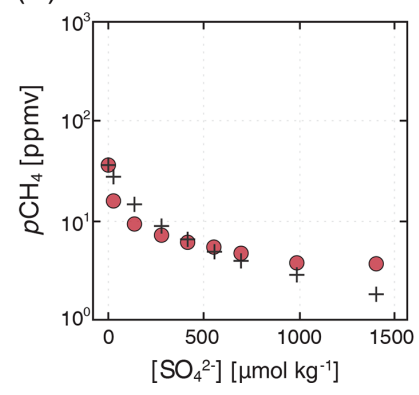

(c)

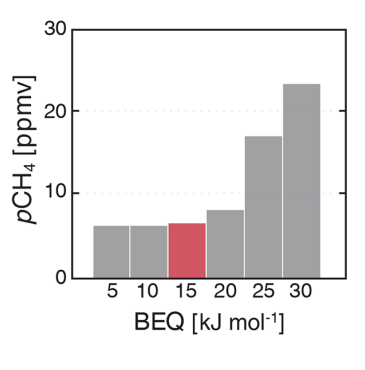

Figure 10. Sensitivity ensembles of our "ancient" configuration compared to the results of Olson et al. (2016). Steady-state atmospheric $p \mathrm{CH}_{4}$ values as a function of assumed atmospheric $p \mathrm{O}_{2}$ (a) and initial marine $\mathrm{SO}_{4}^{2-}$ inventory (b) are shown for our "ancient" configuration (filled circles; see text) and from Olson et al. (black crosses). Shown below are additional ensembles showing the impact of varying the minimum free energy yield required for microbial methane oxidation (BEQ; $\mathbf{c}$ ) on atmospheric $p \mathrm{CH}_{4}$. All simulations were spun up from cold for $20 \mathrm{kyr}$, with the results shown from the last model year.

flexible parameterization of atmospheric photochemistry that allows the roles of atmospheric temperature structure, water vapor abundance, and atmospheric $p \mathrm{CO}_{2}$ to be explored; (3) coupling of deep ocean chemistry with a description of marine methane hydrates and associated sedimentary $\mathrm{CH}_{4}$ cycling; and (4) developing a representation of the production and consumption of $\mathrm{CH}_{4}$ by terrestrial ecosystems.

Code availability. A manual describing code installation, basic model configuration, and an extensive series of tutorials is provided. The Latex source of the manual and PDF file can be obtained by cloning (https://github.com/derpycode/muffindoc, last access: 15 November 2020). The user manual contains instructions for obtaining, installing, and testing the code, as well as running experiments. The version of the code used in this paper is tagged as release v0.9.14 and has the DOI https://doi.org/10.5281/zenodo.4002934 (Ridgewell et al., 2020). Configuration files for the specific experiments presented in the paper can be found in cgenie.muffin/genieuserconfigs/MS/reinhardetal.GMD.2020. Details on the different experiments, plus the command line needed to run each, are given in README.txt.

Data availability. The rate data used to construct Fig. 2 are also included in the Supplement and as an accessory dataset with the DOI https://doi.org/10.5281/zenodo.4081700 (Reinhard, 2020).

Supplement. The supplement related to this article is available online at: https://doi.org/10.5194/gmd-13-5687-2020-supplement.

Author contributions. CTR, SLO, and AR developed new model code. CTR and CP compiled and analyzed empirical data for rates of methanotrophy. CTR performed all model simulations and data analysis. CTR prepared the paper with contributions from all coauthors.
Competing interests. The authors declare that they have no conflict of interest.

Acknowledgements. Christopher T. Reinhard acknowledges support from the NASA Astrobiology Institute (NAI) and the NASA Nexus for Exoplanet System Science (NExSS). SLO acknowledges support from the T.C. Chamberlin Postdoctoral Fellowship in the Department of Geophysical Sciences at the University of Chicago. Andy Ridgwell, Sandra Kirtland Turner, and Yoshiki Kanzaki were supported in part by an award from the Heising-Simons Foundation. We also thank Mark Claire for providing unpublished photochemical model results.

Financial support. This research has been supported by the NASA Astrobiology Institute (CAN7) and the NASA Exobiology Program (proposal 18-EXO18-0005).

Review statement. This paper was edited by Fiona O'Connor and reviewed by David Archer and Jeff Ridley.

\section{References}

Archer, D. and Buffett, B.: Time-dependent response of the global ocean clathrate reservoir to climatic and anthropogenic forcing, Geochem. Geophys., Geosys., 6, GB1008, https://doi.org/10.1029/2004GC000854, 2005.

Archer, D., Buffett, B., and Brovkin, V.: Ocean methane hydrates as a slow tipping point in the global carbon cycle, P. Natl. Acad. Sci. USA, 106, 20596-20601, 2009.

Bartdorff, O., Wallmann, K., Latif, M., and Semenov, V.: Phanerozoic evolution of atmospheric methane, Global Biogeochem. Cy., 22, GB1008, https://doi.org/10.1029/2007GB002985, 2008.

Beerling, D., Berner, R. A., Mackenzie, F. T., Harfoot, M. B., and Pyle, J. A.: Methane and the $\mathrm{CH}_{4}$-related greenhouse effect over the past 400 million years, Am. J. Sci., 309, 97-113, 2009. 
Bender, M. and Conrad, R.: Kinetics of $\mathrm{CH}_{4}$ oxidation in oxic soils exposed to ambient air or high $\mathrm{CH}_{4}$ mixing ratios, Fems. Microbiol. Lett., 101, 261-270, 1992.

Bender, M. and Conrad, R.: Kinetics of methane oxidation in oxic soils, Chemosphere, 26, 687-696, 1993.

Berner, R. A.: Activity Coefficients of Bicarbonate Carbonate and Calcium Ions in Sea Water, Geochim. Cosmochim. Ac., 29, 947965, 1965.

Bethke, C. M., Ding, D., Jin, Q., and Sanford, R. A.: Origin of microbiological zoning in groundwater flows, Geology, 36, 739742, 2008

Bianchi, D., Weber, T. S., Kiko, R., and Deutsch, C.: Global niche of marine anaerobic metabolisms expanded by particle microenvironments, Nat. Geosci., 11, 263-268, 2018.

Bjerrum, C. J. and Canfield, D. E.: Towards a quantitative understanding of the late Neoproterozoic carbon cycle, P. Natl. Acad. Sci. USA, 108, 5542-5547, 2011.

Bock, M., Schmitt, J., Beck, J., Seth, B., Chappellaz, J., and Fischer, H.: Glacial/interglacial wetland, biomass burning, and geologic methane emissions constrained by dual stable isotopic $\mathrm{CH}_{4}$ ice core records, P. Natl. Acad. Sci. USA, 114, E5778-E5786, 2017.

Boetius, A., Ravenschlag, K., Schubert, C. J., Rickert, D., Widdel, F., Gieseke, A., Amann, R., Jørgensen, B. B., Witte, U., and Pfannkuche, O.: A marine microbial consortium apparently mediating anaerobic oxidation of methane, Nature, 407, 623-626, 2000.

Boudreau, B. P.: Diagenetic Models and Their Implementation, Springer-Verlag, Berlin, 1996a.

Boudreau, B. P.: A method-of-lines code for carbon and nutrient diagenesis in aquatic sediments, Comput. Geosci., 22, 479-496, 1996b.

Cao, L., Eby, M., Ridgwell, A., Caldeira, K., Archer, D., Ishida, A., Joos, F., Matsumoto, K., Mikolajewicz, U., Mouchet, A., Orr, J. C., Plattner, G.-K., Schlitzer, R., Tokos, K., Totterdell, I., Tschumi, T., Yamanaka, Y., and Yool, A.: The role of ocean transport in the uptake of anthropogenic $\mathrm{CO}_{2}$, Biogeosciences, 6, 375-390, https://doi.org/10.5194/bg-6-375-2009, 2009.

Catling, D. C., Claire, M. W., and Zahnle, K. J.: Anaerobic methanotrophy and the rise of atmospheric oxygen, Philos. T. R. Soc. A, 365, 1867-1888, 2007.

Chapelle, F. H., McMahon, P. B., Dubrovsky, N. M., Fujii, R. F., Oaksford, E. T., and Vroblesky, D. A.: Deducing the distribution of terminal electron-accepting processes in hydrologically diverse groundwater systems, Water Resour. Res., 31, 359-371, 1995.

Chronopoulou, P.-M., Shelley, F., Pritchard, W. J., Maanoja, S., and Trimmer, M.: Origin and fate of methane in the Eastern Tropical North Pacific oxygen minimum zone, ISME J., 11, 1386-1399, 2017.

Ciais, P., Sabine, C., Bala, G., Bopp, L., Brovkin, V., Canadell, J., Chhabra, A., DeFries, R., Galloway, J., Heimann, M., Jones, C., Le Quéré, C., Myneni, R. B., Piao, S., and Thornton, P.: Carbon and Other Biogeochemical Cycles, in: Climate Change 2013: The Physical Science Basis. Contribution of Working Group I to the Fifth Assessment Report of the Intergovernmental Panel on Climate Change, edited by: Stocker, T. F., Qin, D., Plattner, G.K., Tignor, M., Allen, S. K., Boschung, J., Nauels, A., Xia, Y., Bex, V., and Midgley, P. M., Cambridge University Press, Cambridge, 467-544, 2013.
Claire, M. W., Catling, D. C., and Zahnle, K. J.: Biogeochemical modelling of the rise in atmospheric oxygen, Geobiology, 4, 239-269, 2006.

Clegg, S. L. and Brimblecombe, P.: The solubility and activity coefficient of oxygen in salt solutions and brines, Geochim. Cosmochim. Ac., 54, 3315-3328, 1990.

Cramer, S. D.: Solubility of methane in brines from 0 to $300^{\circ} \mathrm{C}$, Ind. Eng. Chem. Proc. Dd., 23, 533-538, 1984.

Crespo-Medina, M., Meile, C. D., Hunter, K. S., Diercks, A.-R., Asper, V. L., Orphan, V. J., Tavormina, P. L., Nigro, L. M., Battles, J. J., Chanton, J. P., Shiller, A. M., Joung, D.-J., Amon, R. M. W., Bracco, A., Montoya, J. P., Villareal, T. A., Wood, A. M., and Joye, S. B.: The rise and fall of methanotrophy following a deepwater oil-well blowout, Nat. Geosci., 7, 423-427, 2014.

Crowe, S. A., Paris, G., Katsev, S., Jones, C., Kim, S., Zerkle, A. L., Nomosatryo, S., Fowle, D. A., Adkins, J. F., Sessions, A. L., Farquhar, J., and Canfield, D. E.: Sulfate was a trace constituent of Archean seawater, Science, 346, 735-739, 2014.

Curtis, G. P.: Comparison of approaches for simulating reactive solute transport involving organic degredation reactions by multiple terminal electron acceptors, Comput. Geosci., 29, 319-329, 2003.

Daines, S. J. and Lenton, T. M.: The effect of widespread early aerobic marine ecosystems on methane cycling and the Great Oxidation, Earth Planet. Sc. Lett., 434, 42-51, 2016.

Dale, A. W., Regnier, P., and Van Cappellen, P.: Bioenergetic controls on anaerobic oxidation of methane (AOM) in coastal marine sediments: A theoretical analysis, Am. J. Sci., 306, 246-294, 2006.

Dale, A. W., Regnier, P., Knab, N. J., Jørgensen, B. B., and Van Cappellen, P.: Anaerobic oxidation of methane (AOM) in marine sediments from the Skagerrak (Denmark): II. Reaction-transport modeling, Geochim. Cosmochim. Ac., 72, 2880-2894, 2008

Dickens, G. R., Castillo, M. M., and Walker, J. C. G.: A blast of gas in the latest Paleocene: simulating first-order effects of massive dissociation of oceanic methane hydrate, Geology, 25, 259-262, 1997.

Dickens, G. R.: Rethinking the global carbon cycle with a large, dynamic and microbially mediated gas hydrate capacitor, Earth Planet. Sc. Lett., 213, 169-183, 2003.

Doney, S. C., Lindsay, K., Fung, I., and John, J.: Natural variability in a stable, 1000-yr global coupled climate-carbon cycle simulation, J. Climate, 19, 3033-3054, 2006.

Duan, Z., Møller, N., Greenberg, J., and Weare, J. H.: The prediction of methane solubility in natural waters to high ionic strength from 0 to $250^{\circ} \mathrm{C}$ and from 0 to 1600 bar, Geochim. Cosmochim. Ac., 56, 1451-1460, 1992.

Dunfield, P. F. and Conrad, R.: Starvation alters the apparent halfsaturation constant for methane in the Type II methanotroph Methylocystis strain LR1, Appl. Environ. Microb., 66, 41364138, 2000.

Edwards, N. R. and Marsh, R.: Uncertainties due to transportparameter sensitivity in an efficient 3-D ocean-climate model, Clim. Dynam., 24, 415-433, 2005.

Egger, M., Rasigraf, O., Sapart, C. J., Jilbert, T., Jetten, M. S. M., Röckmann, T., van der Veen, C., Banda, N., Kartal, B., Ettwig, K. F., and Slomp, C. P.: Iron-mediated anaerobic oxidation of methane in brackish coastal sediments, Environ. Sci. Technol., 49, 277-283, 2015. 
Egger, M., Riedinger, N., Mogollón, J. M., and Jørgensen, B. B.: Global diffusive fluxes of methane in marine sediments, Nat. Geosci., 11, 421-425, 2018.

Elliot, S., Maltrud, M., Reagan, M., Moridis, G., and CameronSmith, P.: Marine methane cycle simulations for the period of early global warming, J. Geophys. Res.-Biogeo., 116, G01010, https://doi.org/10.1029/2010JG001300, 2011.

Froelich, P. N., Klinkhammer, G. P., Bender, M. L., Luedtke, N. A., Heath, G. R., Cullen, D., and Duaphin, P.: Early oxidation of organic matter in pelagic sediments of the eastern equatorial Atlantic: suboxic diagenesis, Geochim. Cosmochim. Ac., 43, 1075-1090, 1979.

Goldblatt, C., Lenton, T. M., and Watson, A. J.: Bistability of atmospheric oxygen and the Great Oxidation, Nature, 443, 683-686, 2006.

Griffies, S. M.: The Gent-McWilliams skew flux, J. Phys. Oceanogr., 28, 831-841, 1998.

Hanson, R. S. and Hanson, T. E.: Methanotrophic bacteria, Microbiol. Rev., 60, 439-471, 1996.

Haqq-Misra, J., Domagal-Goldman, S. D., Kasting, P. J., and Kasting, J. F.: A revised, hazy methane greenhouse for the Archean Earth, Astrobiol., 8, 1127-1137, 2008.

Haroon, M. F., Hu, S., Shi, Y., Imelfort, M., Keller, J., Hugenholtz, P., Yuan, Z., and Tyson, G. W.: Anaerobic oxidation of methane coupled to nitrate reduction in a novel archaeal lineage, Nature, 500, 567-570, 2013.

Hayes, J. M.: Global methanotrophy at the Archean-Proterozoic transition, in: Nobel Symp. 84, Early Life on Earth, edited by: Bengston, S., Columbia University Press, New York, 220-236, 1994.

Helz, G. R., Bura-Nakíc, E., Mikac, N., and Ciglenecki, I.: New model for molybdenum behavior in euxinic waters, Chem. Geol., 284, 323-332, 2011.

Hinrichs, K.-U., Hayes, J. M., Sylva, S. P., Brewer, P. G., and DeLong, E. F.: Methane-consuming archaebacteria in marine sediments, Nature, 398, 802-805, 1999.

Hinrichs, K.-U.: Microbial fixation of methane carbon at $2.7 \mathrm{Ga}$ : Was an anaerobic mechanism possible?, Geochem. Geophy. Geosy., 3, 1-10, 2002.

Hitchcock, D. R. and Lovelock, J. E.: Life detection by atmospheric analysis, Icarus, 7, 149-159, 1967.

Hoehler, T. M., Alperin, M. J., Albert, D. B., and Martens, C. S.: Field and laboratory studies of methane oxidation in an anoxic marine sediments: Evidence for a methanogen-sulfate reducer consortium, Global Biogeochem. Cy., 8, 451-463, 1994.

Hoehler, T. M., Alperin, M. J., Albert, D. B., and Martens, C. S.: Apparent minimum free energy requirements for methanogenic Archaean and sulfate-reducing bacteria in an anoxic marine sediment, Fems. Microbiol. Ecol., 38, 33-41, 2001.

Hoehler, T. M.: Biological energy requirements as quantitative boundary conditions for life in the subsurface, Geobiology, 2, 205-215, 2004.

Hunter, S. J., Goldobin, D. S., Haywood, A. M., Ridgwell, A., and Rees, J. G.: Sensitivity of the global submarine hydrate inventory to scenarios of future climate change, Earth Planet. Sc. Lett., 367, 105-115, 2013.

Jakobsen, R. and Postma, D.: Redox zoning, rates of sulfate reduction and interactions with Fe-reduction and methanogenesis in a shallow sandy aquifer, Rømø, Denmark, Geochim. Cosmochim. Ac., 63, 137-151, 1999.

Jayakumar, D. A., Naqvi, S. W. A., Narvekar, P. V., and George, M. D.: Methane in coastal and offshore waters of the Arabian Sea, Mar. Chem., 74, 1-13, 2001.

Jin, Q. and Bethke, C. M.: Predicting the rate of microbial respiration in geochemical environments, Geochim. Cosmochim. Ac., 69, 1133-1143, 2005.

Jin, Q. and Bethke, C. M.: The thermodynamics and kinetics of microbial metabolism, Am. J. Sci., 307, 643-677, 2007.

Johnson, K. S.: Carbon dioxide hydration and dehydration kinetics in seawater, Limnol. Oceanogr., 27, 849-855, 1982.

Kasting, J. F., Zahnle, K. J., and Walker, J. C. G.: Photochemistry of methane in the Earth's early atmosphere, Precambrian Res., 20, 121-148, 1983.

Kasting, J. F., Pavlov, A. A., and Siefert, J. L.: A coupled ecosystem-climate model for predicting the methane concentration in the Archean atmosphere, Origin of life and evolution of the Biosphere, 31, 271-285, 2001.

Kessler, J. D., Valentine, D. L., Redmond, M. C., Du, M., Chan, E. W., Mendes, S. D., Quiroz, E. W., Villanueva, C. J., Shusta, S. S., Werra, L. M., Yvon-Lewis, S. A., and Weber, T. C.: A persistent oxygen anomaly reveals the fate of spilled methane in the deep Gulf of Mexico, Science, 331, 312-315, 2011.

Kirschke, S., Bousquet, P., Ciais, P., Saunois, M., Canadell, J. G., Dlugokencky, E. J., Bergamaschi, P., Bergmann, D., Blake, D. R., Bruhwiler, L., Cameron-Smith, P., Castaldi, S., Chevallier, F., Feng, L., Fraser, A., Heimann, M., Hodson, E. L., Houweling, S., Josse, B., Fraser, P. J., Krummel, P. B., Lamarque, J.-F., Langenfelds, R. L., Le Quére, C., Naik, V., O’Doherty, S., Palmer, P. I., Pison, I., Plummer, D., Poulter, B., Prinn, R. G., Rigby, M., Ringeval, B., Santini, M., Schmidt, M., Shindell, D. T., Simpson, I. J., Spahni, R., Steele, L. P., Strode, S. A., Sudo, K., Szopa, S., van der Werf, G. R., Voulgarakis, A., van Weele, M., Weiss, R. F., Williams, J. E., and Zeng, G.: Three decades of global methane sources and sinks, Nat. Geosci., 6, 813-823, 2013.

Kirtland Turner, S. and Ridgwell, A.: Development of a novel empirical framework for interpreting geological carbon isotope excursions, with implications for the rate of carbon injection across the PETM, Earth Planet. Sc. Lett., 435, 1-13, 2016.

Kirtland Turner, S.: Constraints on the onset duration of the Paleocene-Eocene Thermal Maximum, Philos. T. Roy. Soc. A, 376, 20170082, https://doi.org/10.1098/rsta.2017.0082, 2018.

Konijnendijk, T. Y. M., Weber, S. L., Tuenter, E., and van Weele, M.: Methane variations on orbital timescales: a transient modeling experiment, Clim. Past, 7, 635-648, https://doi.org/10.5194/cp-7-635-2011, 2011.

Krissansen-Totton, J., Garland, R., Irwin, P., and Catling, D. C.: Detectability of biosignatures in anoxic atmospheres with the James Webb Space Telescope: A TRAPPIST-1e cast study, Astro. J., 156, 114, https://doi.org/10.3847/1538-3881/aad564, 2018.

Kuivila, K. M., Murray, J. W., and Devol, A. H.: Methane production, sulfate reduction and competition for substrates in the sediments of Lake Washington, Geochim. Cosmochim. Ac., 53, 409416, 1989.

Lamarque, J.-F., Kiehl, J. T., Shields, C. A., Boville, B. A., and Kinnison, D. E.: Modeling the response to changes in tropospheric methane concentration: Application to the 
Permian-Triassic boundary, Paleoceanography, 21, PA3006, https://doi.org/10.1029/2006PA001276, 2006.

Lovley, D. R., Dwyer, D. F., and Klug, M. J.: Kinetic analysis of competition between sulfate reducers and methanogens for hydrogen in sediments, Appl. Environ. Microb., 43, 1373-1379, 1982.

Lunt, D. J., Ridgwell, A., Sluijs, A., Zachos, J. C., Hunter, S. J., and Haywood, A.: A model for orbital pacing of methane hydrate destabilization during the Palaeogene, Nat. Geosci., 4, 775-778, 2011.

Marsh, R., Müller, S. A., Yool, A., and Edwards, N. R.: Incorporation of the C-GOLDSTEIN efficient climate model into the GENIE framework: "eb_go_gs" configurations of GENIE, Geosci. Model Dev., 4, 957-992, https://doi.org/10.5194/gmd-4957-2011, 2011.

Martens, C. S. and Berner, R. A.: Interstitial water chemistry of anoxic Long Island Sound sediments. 1. Dissolved gases, Limnol. Oceanogr., 22, 10-25, 1977.

McGlynn, S. E., Chadwick, G. L., Kempes, C. P., and Orphan, V. J.: Single cell activity reveals direct electron transfer in methanotrophic consortia, Nature, 526, 531-535, 2015.

Melton, J. R., Wania, R., Hodson, E. L., Poulter, B., Ringeval, B., Spahni, R., Bohn, T., Avis, C. A., Beerling, D. J., Chen, G., Eliseev, A. V., Denisov, S. N., Hopcroft, P. O., Lettenmaier, D. P., Riley, W. J., Singarayer, J. S., Subin, Z. M., Tian, H., Zürcher, S., Brovkin, V., van Bodegom, P. M., Kleinen, T., Yu, Z. C., and Kaplan, J. O.: Present state of global wetland extent and wetland methane modelling: conclusions from a model intercomparison project (WETCHIMP), Biogeosciences, 10, 753788, https://doi.org/10.5194/bg-10-753-2013, 2013.

Meyer, K. M., Ridgwell, A., and Payne, J. L.: The influence of the biological pump on ocean chemistry: implications for long-term trends in marine redox chemistry, the global carbon cycle, and marine animal ecosystems, Geobiology, 14, 207-219, 2016.

Milucka, J., Ferdelman, T. G., Polerecky, L., Franzke, D., Wegener, G., Schmid, M., Lieberwirth, I., Wagner, M., Widdel, F., and Kuypers, M. M. M.: Zero-valent sulphur is a key intermediate in marine methane oxidation, Nature, 491, 541-546, 2012.

Myhre, G., Shindell, D., Breon, F.-M., Collins, W., Fuglestvedt, J., Huang, J., Koch, D., Lamarque, J.-F., Lee, D., Mendoza, B., Nakajima, T., Robock, A., Stephens, G., Takemura, T., and Zhang, H.: Anthropogenic and natural radiative forcing, in: Climate Change 2013: The Physical Science Basis. Contribution of Working Group I to the Fifth Assessment Report of the Intergovernmental Panel on Climate Change, edited by: Stocker, T. F., Qin, D., Plattner, G.-K., Tignor, M., Allen, S. K., Boschung, J., Nauels, A., Xia, Y., Bex, V., and Midgley, P. M., Cambridge University Press, Cambridge, 659-740, 2013.

Olson, S. L., Kump, L. R., and Kasting, J. F.: Quantifying the areal extent and dissolved oxygen concentrations of Archean oxygen oases, Chem. Geol., 362, 35-43, 2013.

Olson, S. L., Reinhard, C. T., and Lyons, T. W.: Limited role for methane in the mid-Proterozoic greenhouse, P. Natl. Acad. Sci. USA, 113, 11447-11452, 2016.

Orphan, V. J., House, C. H., Hinrichs, K.-U., McKeegan, K. D., and DeLong, E. F.: Methane-consuming Archaea revealed by directly coupled isotopic and phylogenetic analysis, Science, 293, 484487, 2001
Ozaki, K., Tajika, E., Hong, P. K., Nakagawa, Y., and Reinhard, C. T.: Effects of primitive photosynthesis on Earth's early climate system, Nat. Geosci., 11, 55-59, 2018.

Paudel, R., Mahowald, N. M., Hess, P. G. M., Meng, L., and Riley, W. J.: Attribution of changes in global wetland methane emissions from pre-industrial to present using CLM4.5-BGC, Environ. Res. Lett., 11, 034020, https://doi.org/10.1088/17489326/11/3/034020, 2016.

Pavlov, A. A. and Kasting, J. F.: Mass-independent fractionation of sulfur isotopes in Archean sediments: Strong evidence for an anoxic Archean atmosphere, Astrobiology, 2, 27-41, 2002.

Pavlov, A. A., Kasting, J. F., and Brown, L. L.: Greenhouse warming by $\mathrm{CH}_{4}$ in the atmosphere of early Earth, J. Geophys. Res., 105, 11981-11990, 2000.

Pavlov, A. A., Hurtgen, M. T., Kasting, J. F., and Arthur, M. A.: Methane-rich Proterozoic atmosphere?, Geology, 31, 87-90, 2003.

Prather, M. J.: Time scales in atmospheric chemistry: Theory, GWPs for $\mathrm{CH}_{4}$ and $\mathrm{CO}$, and runaway growth, Geophys. Res. Lett., 23, 2597-2600, 1996.

Rabouille, C. and Gaillard, J. F.: A coupled model representing the deep-sea organic carbon mineralization and oxygen consumption in surficial sediments, J. Geophys. Res.-Oceans., 96, 2761-2776, https://doi.org/10.1029/90jc02332, 1991.

Reeburgh, W. S.: Methane consumption in Cariaco Trench waters and sediments, Earth Planet. Sc. Lett., 28, 337-344, 1976.

Reeburgh, W. S.: Oceanic methane biogeochemistry, Chem. Rev., 107, 486-513, 2007.

Regnier, P., Dale, A. W., Arndt, S., LaRowe, D. E., Mogollón, J., and Van Cappellen, P.: Quantitative analysis of anaerobic oxidation of methane (AOM) in marine sediments: A modeling perspective, Earth-Sci. Rev., 106, 105-130, 2011.

Reinhard, C. T.: Reinhard.GMD.2020.RateData [Data set], Zenodo, https://doi.org/10.5281/zenodo.4081700, 2020.

Reinhard, C. T., Planavsky, N. J., Olson, S. L., Lyons, T. W., and Erwin, D. H.: Earth's oxygen cycle and the evolution of animal life, P. Natl. Acad. Sci. USA, 113, 8933-8938, 2016.

Reinhard, C. T., Olson, S. L., Schwieterman, E. W., and Lyons, T. W.: False negatives for remote life detection on ocean-bearing planets: Lessons from the early Earth, Astrobiology, 17, 287297, https://doi.org/10.1089/ast.2016.1598, 2017.

Ridgwell, A.: Glacial-interglacial perturbations in the global carbon cycle, PhD thesis, University of East Anglia, Norwich, UK, 2001.

Ridgwell, A., Hargreaves, J. C., Edwards, N. R., Annan, J. D., Lenton, T. M., Marsh, R., Yool, A., and Watson, A.: Marine geochemical data assimilation in an efficient Earth System Model of global biogeochemical cycling, Biogeosciences, 4, 87-104, https://doi.org/10.5194/bg-4-87-2007, 2007.

Ridgwell, A. J., Marshall, S. J., and Gregson, K.: Consumption of atmospheric methane by soils: A process-based model, Global Biogeochem. Cy., 13, 59-70, 1999.

Sagan, C. and Mullen, G.: Earth and Mars: Evolution of atmospheres and surface temperatures, Science, 177, 52-56, 1972.

Sagan, C., Thompson, W. R., Carlson, R., Gurnett, D., and Hord, C.: A search for life on Earth from the Galileo spacecraft, Nature, 365, 715-721, 1993.

Sansone, F. J., Popp, B. N., Gasc, A., Graham, A. W., and Rust, T. M.: Highly elevated methane in the eastern tropical North Pacific 
and associated isotopically enriched fluxes to the atmosphere, Geophys. Res. Lett., 28, 4567-4570, 2001.

Schink, B.: Energetics of syntrophic cooperation in methanogenic degradation, Microbiol. Mol. Biol. R., 61, 262-280, 1997.

Schmidt, G. A. and Shindell, D. T.: Atmospheric composition, radiative forcing, and climate change as a consequence of a massive methane release from gas hydrates, Paleoceanography, 18, 1004, https://doi.org/10.1029/2002PA000757, 2003.

Schrag, D. P., Berner, R. A., Hoffman, P. F., and Halverson, G. P.: On the initiation of a snowball Earth, Geochem. Geophys. Geosyst., 3, https://doi.org/10.1029/2001GC000219, 2002.

Scranton, M. I. and Brewer, P. G.: Consumption of dissolved methane in the deep ocean, Limnol. Oceanogr., 23, 1207-1213, 1978.

Shindell, D. T., Pechony, O., Voulgarakis, A., Faluvegi, G., Nazarenko, L., Lamarque, J.-F., Bowman, K., Milly, G., Kovari, B., Ruedy, R., and Schmidt, G. A.: Interactive ozone and methane chemistry in GISS-E2 historical and future climate simulations, Atmos. Chem. Phys., 13, 2653-2689, https://doi.org/10.5194/acp-13-2653-2013, 2013.

Sivan, O., Adler, M., Pearson, A., Gelman, F., Bar-Or, I., John, S. G., and Eckert, W.: Geochemical evidence for iron-mediated anaerobic oxidation of methane, Limnol. Oceanogr., 56, 15361544, 2011.

Stoessell, R. K. and Byrne, P. A.: Salting-out of methane in singlesalt solutions at $25^{\circ} \mathrm{C}$ and below 800 psia, Geochim. Cosmochim. Ac., 46, 1327-1332, 1982.

Thamdrup, B., Steinsdóttir, H. G. R., Bertagnolli, A. D., Padilla, C. C., Patin, N. V., Garcia-Robledo, E., Bristow, L. A., and Stewart, F. J.: Anaerobic methane oxidation is an important sink for methane in the ocean's largest oxygen minimum zone, Limnol. Oceanogr., 64, 2569-2585, https://doi.org/10.1002/lno.11235, 2019.

Thompson, A. M. and Cicerone, R. J.: Possible perturbations to atmospheric $\mathrm{CO}, \mathrm{CH}_{4}$, and $\mathrm{OH}$, J. Geophys. Res., 91, 1085310864, 1986.
Ueno, Y., Yamada, K., Yoshida, N., Maruyama, S., and Isozaki, Y.: Evidence from fluid inclusions for microbial methanogenesis in the early Archaean era, Nature, 440, 516-519, 2006.

Ulfsbo, A., Abbas, Z., and Turner, D. R.: Activity coefficients of a simplified seawater electrolyte at varying salinity (5-40) and temperature $\left(0\right.$ and $\left.25^{\circ} \mathrm{C}\right)$ using Monte Carlo simulations, Mar. Chem., 171, 78-86, 2015.

Valentine, D. L.: Emerging topics in marine methane biogeochemistry, Annu. Rev. Mar. Sci., 3, 147-171, 2011.

van Bodegom, P., Stams, F., Liesbeth, M., Boeke, S., and Leffelaar, P.: Methane oxidation and the competition for oxygen in the rice rhizosphere, Appl. Environ. Microb., 67, 3586-3597, 2001.

Van Cappellen, P., Gaillard, J.-F., and Rabouille, C.: Biogeochemical transformations in sediments: Kinetic models of early diagenesis, in: Interactions of C, N, P and S Biogeochemical Cycles and Global Change, Springer-Verlag, Berlin, 401-445, 1993.

Walter, B. P. and Heimann, M.: A process-based, climate-sensitive model to derive methane emissions from natural wetlands: Application to five wetland sites, sensitivity to model parameters, and climate, Global Biogeochem. Cy., 14, 745-765, 2000.

Wania, R., Ross, I., and Prentice, I. C.: Implementation and evaluation of a new methane model within a dynamic global vegetation model: LPJ-WHyMe v1.3.1, Geosci. Model Dev., 3, 565-584, https://doi.org/10.5194/gmd-3-565-2010, 2010.

Weber, T., Wiseman, N. A., and Kock, A.: Global ocean methane emissions dominated by shallow coastal waters, Nat. Commun., 10, 4584, https://doi.org/10.1038/s41467-019-12541-7, 2019.

Zeebe, R. E., Zachos, J. C., and Dickens, G. R.: Carbon dioxide forcing alone insufficient to explain Palaeocene-Eocene Thermal Maximum warming, Nat. Geosci., 2, 576-580, 2009.

Zeebe, R. E.: What caused the long duration of the PaleoceneEocene Thermal Maximum?, Paleoceanography, 28, 1-13, https://doi.org/10.1002/palo.20039, 2013. 